\title{
Learning from Monocyte-Macrophage Fusion and Multinucleation: Potential Therapeutic Targets for Osteoporosis and Rheumatoid Arthritis
}

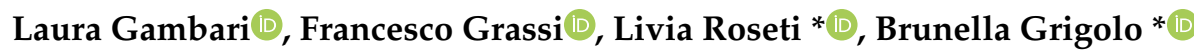 \\ and Giovanna Desando (D) \\ IRCCS Istituto Ortopedico Rizzoli, Laboratorio RAMSES, 40136 Bologna, Italy; laura.gambari@ior.it (L.G.); \\ francesco.grassi@ior.it (F.G.); giovanna.desando@ior.it (G.D.) \\ * Correspondence: livia.roseti@ior.it (L.R.); brunella.grigolo@ior.it (B.G.); Tel.: +39-051-6366090 (B.G.)
}

Received: 31 July 2020; Accepted: 18 August 2020; Published: 20 August 2020

\begin{abstract}
Excessive bone resorption by osteoclasts (OCs) covers an essential role in developing bone diseases, such as osteoporosis (OP) and rheumatoid arthritis (RA). Monocytes or macrophages fusion and multinucleation (M-FM) are key processes for generating multinucleated mature cells with essential roles in bone remodelling. Depending on the phenotypic heterogeneity of monocyte/macrophage precursors and the extracellular milieu, two distinct morphological and functional cell types can arise mature OCs and giant cells (GCs). Despite their biological relevance in several physiological and pathological responses, many gaps exist in our understanding of their formation and role in bone, including the molecular determinants of cell fusion and multinucleation. Here, we outline fusogenic molecules during M-FM involved in OCs and GCs formation in healthy conditions and during OP and RA. Moreover, we discuss the impact of the inflammatory milieu on modulating macrophages phenotype and their differentiation towards mature cells. Methodological approach envisaged searches on Scopus, Web of Science Core Collection, and EMBASE databases to select relevant studies on M-FM, osteoclastogenesis, inflammation, OP, and RA. This review intends to give a state-of-the-art description of mechanisms beyond osteoclastogenesis and M-FM, with a focus on OP and RA, and to highlight potential biological therapeutic targets to prevent extreme bone loss.
\end{abstract}

Keywords: bone loss; osteoporosis; rheumatoid arthritis; macrophage fusion and multinucleation; osteoclasts; giant cells; inflammation; macrophage polarisation; natural compounds

\section{Introduction}

Bone diseases, such as osteoporosis (OP) and rheumatoid arthritis (RA), are an enormous burden for the healthcare system worldwide, mainly due to the enhanced risk for bone fractures [1]. Both diseases display excessive bone resorption by osteoclasts (OCs), leading to bone destruction. In OP, the bone loss depends on the impaired bone remodelling. Uncoupling between bone formation supported by osteoblasts (OBs) and bone resorption by OCs in favour of resorption activity is one of the main pathognomonic mechanisms in OP [2]. In RA, the hyperproduction of inflammatory cytokines and matrix-degrading enzymes from activated immune cells in the synovial membrane contributes to driving joint destruction, including subchondral bone loss [3]. Besides their role in the immune system, many inflammatory cytokines modulate OCs recruitment and differentiation and OBs activity, leading to lower bone formation at sites of bone erosion [4,5]. Beyond OCs, emerging cell players are multinucleated giant cells (GCs) [6]. Despite their different functions, OCs and GCs share a common origin because they derive from the differentiation and fusion of monocyte-macrophage lineage progenitors [7]. 
Interestingly, monocytes and macrophages exhibit a pronounced fusogenic potential. Depending on the anatomical site and environmental milieu, they can create two specific cell types: mature OCs in bone and GCs as part of the immune response [7]. A typical characteristic of OCs and GCs is multinucleation, an essential step for promoting their maturation $[8,9]$. Defective multinucleation of OCs and GCs leads, respectively, to impaired bone resorption [9] and increased susceptibility to chronic inflammatory diseases [6].

In general, OCs regulate bone homeostasis in the entire life course during skeletal growth and development and bone repair following tissue injuries [10,11]. GCs instead enhance tissue-specific phagocytic activity when macrophages are not sufficient [12]. In pathological conditions related to inflammation, GCs produce specific signals, which can stimulate monocyte subset to differentiate into OCs [13-15]. RA patients show GCs distribution not only in the subchondral bone tissue but also in the cartilage and synovial membrane, and their number correlates with synovitis severity and enhanced OCs numbers in the bone [15].

Altogether, M-FM stands at the interface between physiological and pathological responses because it is modulated by several cells and molecular signalling pathways, which are still far to be elucidated. Gathering a better grasp of cellular and molecular mechanisms involved in M-FM can offer valuable prospects on potential biological targets for treating OP and RA. In this review, we intend to present an overview of how several modulators influence M-FM during bone matrix turnover and inflammatory conditions by highlighting the gaps remaining in the literature. Finally, we discuss challenges and prospects to improve therapeutic alternatives for OP and RA.

\section{M-FM during Normal Osteoclastogenesis: Therapeutic Perspectives for OP}

\subsection{Morphological Features of OCs in Physiological Conditions}

OCs are bone-resorbing cells which can arise from immature monocytes and mature tissue macrophages [16]. Immature cells from the monocyte-macrophage lineage upon macrophage colony-stimulating factor (M-CSF) and receptor activator for nuclear factor $\mathrm{k} B$ ligand (RANKL) differentiate into OCs. Mature OCs are multinucleated (2-20 nuclei) cells (up to $100 \mu \mathrm{m}$ ) with a polarised conformation. Not all the nuclei of OCs are transcriptionally active in each stage of differentiation. Nuclear factor of activated T-cell cytoplasmic 1 (NFATc1) is a master transcription factor for OCs differentiation, present in most nuclei only in early differentiated OCs and at a less extent in further stages [17]. OCs show a large cytoplasm volume per each nucleus and enclose many vacuoles, mitochondria and lysosomes. OCs surface membrane displays four domains: the sealing zone (SZ), the ruffled border (RB), the basolateral domain (BD) and the functional secretory domain (FSD) [18]. $\mathrm{SZ}$ is a dynamic actin-rich structure that keeps the boundary for the resorption area of the bone [19]. RB also called as specialised lysosome-related organelle (LRO), functions as the OCs' secretory apparatus for protons $\left(\mathrm{H}^{+}\right)$, chloride ions $\left(\mathrm{Cl}^{-}\right)$, and proteases during bone degradation $[18,20]$. $\mathrm{BD}$ is the site where endocytosis occurs [21], whereas FSD regulates the trafficking and secretion of vesicles [18]. Cell-cell fusion requires cytoskeleton rearrangement and assembly, cell polarisation and multinucleation of competent cells. In particular, the size and the number of multi-nuclei of OCs depend on the status of the actin cytoskeleton signalling [22]. Several authors described a direct relationship between OCs size and resorption activity. A 10-fold increase in cell radius results in a 10-fold increase in resorption areas because of more energy (ATP) and release of proteases [23]. The large OCs size is attained either through monocyte fusion, or through fusion-independent cytoplasm growth, or with a combination of these processes. Several studies identified a repertoire of actin-rich structures in OCs crucial to the fusion, including circumferential podosomes [24], zipper-like structures (ZLS) [22,25], and tunnelling nanotubes (TNT) [26]. In particular, the formation of ZLS is vital to create a discontinuous broad contact surface between the two apposed plasma membranes of two fusion partners and to produce efficient M-FM; its absence contributes to the formation of smaller OCs [25-27]. 


\subsection{Osteoclastogenesis and Osteoclastic Bone Resorption}

Osteoclastogenesis is a multi-step process, controlled via the spatiotemporal regulation of several differentiation factors, driving OCs maturation and commitment towards bone resorption (Figure 1). Osteoclastogenesis and OCs resorption are energy-consuming processes, bolstered by the mitochondrial oxidative metabolism and the glycolysis [28]. During the initial phases, a gradient of chemokines recruits mononuclear hematopoietic precursors [29]. Macrophage colony-stimulating factor (M-CSF) and receptor activator for nuclear factor $\kappa \mathrm{B}$ ligand (RANKL) activate the OCs differentiation from pre-OCs by binding with their receptors c-fms and RANK. M-CSF is pivotal for stimulating the proliferation and the first stages of OCs maturation. RANK/RANKL and the decoy receptor osteoprotegerin (OPG) are central regulators of OCs development and function [30,31]. The rate of RANKL to OPG in the bone serves as an index of the net stimulus for osteoclastogenesis. Molecular cross-talk between RANK-RANKL determines cytoplasmic $\mathrm{Ca}^{2+}$ oscillations and triggers tumour necrosis factor (TNF) receptor-associated factor (TRAF) family proteins such as TRAF6. RANK-RANKL signalling activates several downstream pathways like nuclear factor-kappa-B (NF-kB), c-Jun N-terminal kinases (JNK) and c-Fos, mitogen-activated protein kinase (MAPK), and protein kinase B (AKT), phosphatidylinositol-3 kinase (PI3K). Activator protein-1 (AP-1), NF- $\mathrm{B}$, NFATc1, tartrate-resistant acid phosphatase (TRAP), cathepsin $\mathrm{K}$ (CTSK) and calcitonin receptor (CTR) are among the central genes needed for OCs development [32]. Osteoclastogenesis also requires co-stimulatory signalling activated by the binding of immunoreceptors tyrosine-based activation motif (ITAM), bearing the adaptors DNAX-activating protein 12 (DAP12) and Fc receptor standard g chain $(\mathrm{FcR} \gamma)$, with other immunoreceptors. DAP12 form a complex with Siglec-15 or TREM2 receptors; FcR $\gamma$ pairs with OCs-specific activating receptor (OSCAR), immunoglobulin receptor A (PIR-A), and Fc receptors. RANKL-NFATc1 signalling also activates B lymphocyte-induced maturation protein 1 (Blimp1), which acts as a transcriptional repressor of anti-osteoclastogenic genes such as Irf8, Mafb, BCL6 [33] and induces various OCs genes like dendritic cell-specific transmembrane protein (DC-STAMP), ATPase H1 transporting V0 subunit d isoform 2 (ATP6V0d2), TRAP, CTSK, and NFATc1 [34]. miRNAs are small non-coding RNA, which regulate several genes at the post-transcriptional level, including those involved in OCs differentiation and fusion [35-37]. As a consequence, their levels of expression are strictly modulated during osteoclastogenesis. The redox balance exerts a vital role in regulating osteoclastogenesis. RANKL induces a transient and fast increase in reactive oxygen species (ROS) through activation of TRAF6, NOX1, RAC1 [31,38], which is critical for OCs differentiation. Finally, key signalling modulating osteoclastogenesis derives from cell-cell contacts mediated by proteins such as ephrins. Interestingly, cell-cell communication between OCs and OBs through ephrinA2 (expressed in OCs downstream to RANKL signalling)-EphA2 (expressed in OBs) activates the initiation phase of bone remodelling by enhancing OCs differentiation and suppressing OBs differentiation [39]. Conversely, cell-cell contact between OCs and OBs through ephrinB2 (expressed in mature OCs)-EphB4 (expressed in OBs precursors) enhances osteogenic differentiation and suppresses OCs function [39].

$\mathrm{M}-\mathrm{FM}$ is the last process in OCs differentiation, critical for ensuring optimal OCs function through cytoskeleton reorganisation and formation of the RB and SZ. After M-FM and the SZ formation, OCs can adhere to the bone via $\alpha \beta 1$ integrin. The SZ maintains local acidification thanks to the ion channels: Clcn7 (which encodes chloride Channel 7), and ATP6v0d2 [40,41]. During OCs resorption, RF releases LRO containing matrix-degrading metalloproteinases (MMPs); TRAP and CTSK [40,41]. 


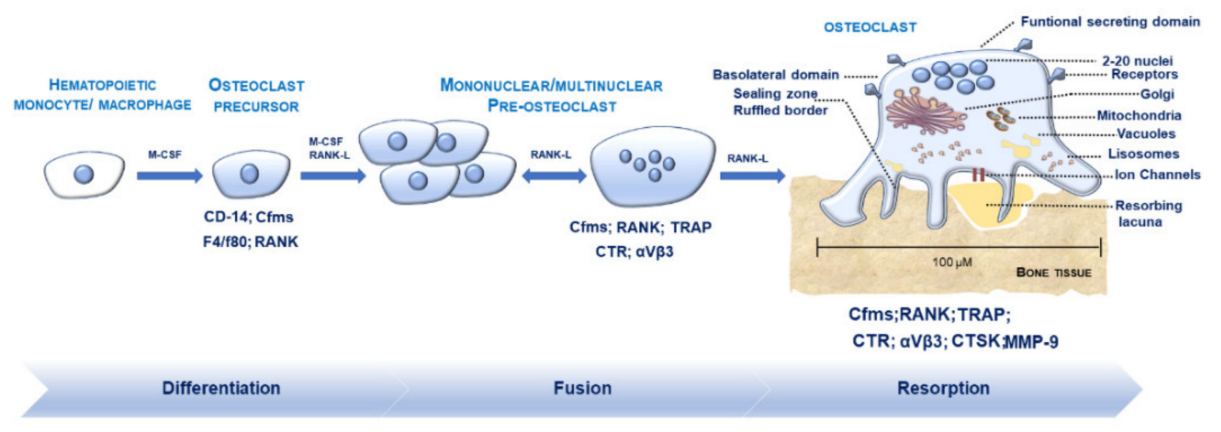

Figure 1. Osteoclasts (OCs) formation and differentiation. Hematopoietic monocytes/macrophages mature into OCs precursors (pre-OCs) (positive for CD-14, Cfms, F4/F80, RANK) after macrophage colony-stimulating factor (M-CSF) stimulation. The addition of M-CSF and receptor activator for nuclear factor $\mathrm{K}$ B ligand (RANK-L) drives differentiation of pre-OCs and fusion towards mature multinucleated OCs (positive for Cfms, RANK, TRAP, CTR, CTSK, MMP-9). OCs display a polarised shape and own up to 2-20 nuclei. OCs surface membrane exhibits channels (responsible for the release of ions and matrix-degrading enzymes favouring bone resorption) and four distinct domains: the sealing zone (SZ), the ruffled border (RB), the basolateral domain (BD), and the functional secretory domain (FSD). Golgi apparatus, mitochondria, lysosomes, vacuoles are within the cytoplasm to support OCs function.

\subsection{Regulators Modulating $M-F M$}

The concept of M-FM as the result of a random cell-cell fusion between mononuclear pre-OCs has evolved [42]. Recent experimental evidence suggests that the fusion process occurs between specific "fusion partners" whose selection depends on the nuclear number, differentiation and mobility level [43]. Differential expression of DC-STAMP, CD47, CxCr3, syncytin-1 in cells at varied maturation stages might drive this "selection" [44]. This autonomous system could prevent pre-OCs fusion in the bone marrow and regulate their size and nuclei number [44]. CD44/MMP-9 complex is a unique motility-enhancing signal [45], critical for both migration and cell fusion [46]. CD44 is a component of the podosome, which binds to hyaluronic acid, collagen, osteopontin, and laminin [47]. CD44 assembles MT1-MMP to the cell surface and regulates MMP-9 activity; thus promoting OCs migration [48]. The chemokine monocyte chemoattractant protein-1 (MCP-1) and its receptor CCR2 have a compelling role in fusion. CCR2 knockout mice showed OCs with smaller size and number of nuclei and overall, a lower number of OCs [49]. MCP-1-deficient mice showed limited multinuclear OCs formation and expression of DC-STAMP, NFATc1, and CTSK [50]. Pre-OCs attachment to the bone matrix launches cell migration and fusion. CD9, DC-STAMP, OC-stimulatory transmembrane protein (OC-STAMP) are among the main modulators involved in cell fusion, regulated by RANKL. OC-STAMP and DC-STAMP are unique OCs-specific fusogenic molecules, whereas CD-9 is a permissive fusogen, not only restricted to OCs $[24,44,51]$. After stimulation with RANKL, OC-STAMP mRNA increases with time, culminates at $48 \mathrm{hrs}$ and later decreases [44]. NFATc1 binds to the promoter of DC-STAMP and increases its expression in pre-OCs [52]. Surface distribution of fusogenic molecules increases in pre-OCs before cell fusion and declines after the fusion [44,51,53-55]. Depletion of CD-9, DC-STAMP, and OC-STAMP suppressed formation of TRAP multinuclear OCs ( $>10$ nuclei/cell) in various studies, leading to inhibition of OCs resorption $[44,51,56,57]$. Syncitin- 1 is another crucial protein, which upholds the fusion of multinucleated cells but not of mononucleated cells [58]. Among membrane proteins, the sialic acid-binding immunoglobulin-type lectin 15 (Siglec-15) rises after RANKL stimulation by NFATc1 $[59,60]$. Siglec-15 functions as a coupling receptor in the co-stimulatory ITAM signalling by cooperating with the adaptor DAP12 [61] and activates different downstream pathways. In specific, it strengthens the phosphorylation of Erk and PI3K/Akt, downstream of RANK-TRAF6 pathway; while the pathway involved in TNF- $\alpha$ stimulation remains uncertain. Siglec-15 is specifically involved 
in M-FM, given that Siglec-15-/- mice display a lower number of multinucleated OCs $[59,62]$ and inhibit OCs activity [63]. Another process critically related to cell fusion is lysosomes trafficking. Rab27a localised in lysosomes increases during OCs differentiation from macrophages and mediates membrane trafficking events. Rab-27a deficient OCs display abnormal lysosomal protein distribution and impaired bone resorption [64]. Osteoclastogenesis-associated transmembrane protein-1 (Ostm1) inhibits OCs fusion by restraining the NFATc1 pathway through the modulation of calcium signalling response [65].

Interestingly, a few miRNAs would seem specifically implicated in OCs fusion. miR7b and miR30a directly target the mRNA of DC-STAMP [37,66]; miR-26a increases the expression of DC-STAMP and ATP6v0d2 by directly targeting connective tissue growth factor/CCN family 2 (CTGF/CCN2) [66]; miRNA124 targets Rab27a [67]. Despite the low knowledge about their control and mechanism of action, they create a fusion-competent status and stimulate fusion between the two lipid bilayer membranes, which do not spontaneously undergo fusion [24]. Several other molecules have been linked to OCs fusion $[55,58,68-85]$ and listed in Table 1 . Moreover, a specific plasma membrane structure is necessary to cell-fusion: the lipid raft domain [51]. Disruption of this domain causes the complete inhibition of the formation of multinuclear OCs in the presence of RANKL [51].

Table 1. Biological targets involved in monocyte-macrophages fusion and multinucleation (M-FM).

\begin{tabular}{|c|c|c|c|}
\hline Biological Target & & Role in M-FM & Refs \\
\hline $\begin{array}{l}\text { CD44/Matrix metallopeptidase } 9 \\
\text { (CD44/MMP-9) }\end{array}$ & - & $\begin{array}{l}\text { Enhances the motility signals for stimulating } \\
\text { cells to migrate and fuse. }\end{array}$ & [45] \\
\hline $\begin{array}{l}\text { Monocyte chemoattractant protein-1/C-C } \\
\text { chemokine receptor type } 2 \\
\text { (MCP-1/CCR2) }\end{array}$ & - & $\begin{array}{l}\text { Crucial for the formation of mature } \\
\text { multinucleated OCs. }\end{array}$ & {$[49,50]$} \\
\hline CD9 & - & Permissive fusogen. & [51] \\
\hline $\begin{array}{l}\text { Dendritic cell-specific } \\
\text { transmembrane protein } \\
\text { (DC-STAMP) }\end{array}$ & - & OCs-specific fusogen. & {$[37,53]$} \\
\hline $\begin{array}{l}\text { OC-stimulatory transmembrane protein } \\
\text { (OC-STAMP) }\end{array}$ & - & OCs-specific fusogen. & {$[44]$} \\
\hline Syncitin-1 & $\mathbf{\square}$ & $\begin{array}{l}\text { Drives the fusion of the plasma membranes } \\
\text { lipid bilayers. } \\
\text { Drives the fusion between multinucleated cells } \\
\text { rather than mononuclear pre-OCs. }\end{array}$ & {$[58]$} \\
\hline $\begin{array}{l}\text { Sialic acid-binding } \\
\text { immunoglobulin-type lectin } 15 \\
\text { (Siglec-15) }\end{array}$ & & $\begin{array}{l}\text { Key to the formation of the actin ring. } \\
\text { Key to the formation of multinucleated OCs. }\end{array}$ & [59-63] \\
\hline $\begin{array}{l}\text { Ras-related protein Rab-27a } \\
\qquad(\text { Rab27a) }\end{array}$ & $\mathbf{\square}$ & $\begin{array}{l}\text { Mediates lysosomes trafficking and } \\
\text { membrane fusion. } \\
\text { Regulates the transport of LRO to modulate } \\
\text { multinucleation and cell size in OCs. }\end{array}$ & [64] \\
\hline $\begin{array}{l}\text { Osteoclastogenesis-associated } \\
\text { transmembrane protein-1 } \\
\text { (Ostm1) }\end{array}$ & - & Inhibits M-FM by targeting NFATc1. & {$[65]$} \\
\hline $\operatorname{miR7b}$ & - & Targets and inhibits DC-STAMP. & [37] \\
\hline miR30a & ! & Targets and inhibits DC-STAMP. & [35] \\
\hline miR-26a & - & Targets CTGF/CCN2 and inhibits DC-STAMP. & {$[66]$} \\
\hline
\end{tabular}


Table 1. Cont.

\begin{tabular}{|c|c|c|c|}
\hline Biological Target & & Role in M-FM & Refs \\
\hline CD47 & $\mathbf{\square}$ & $\begin{array}{l}\text { Key to the fusion of two mono-nucleated } \\
\text { partners or mono- and multinucleated partners. } \\
\text { Promotes the formation of large OCs and } \\
\text { reduces the formation of smaller OCs. }\end{array}$ & [58] \\
\hline $\begin{array}{l}\text { Macrophage fusion receptor } \\
\text { (MFR) }\end{array}$ & - & $\begin{array}{l}\text { Plays a role in macrophage-macrophage } \\
\text { adhesion/fusion leading to multinucleation. }\end{array}$ & {$[7,10]$} \\
\hline E-cadherin & - & $\begin{array}{l}\text { Drives the formation of dynamic membrane } \\
\text { protrusions necessary for migration and fusion. } \\
\text { Promotes the formation of multinucleated OCs. }\end{array}$ & [7] \\
\hline CD-26 & $\mathbf{\square}$ & Key to the formation of multinucleated OCs. & [68] \\
\hline CD-47 & $\mathbf{\square}$ & $\begin{array}{l}\text { Key to the fusion of two mono-nucleated } \\
\text { partners or mono- and multinucleated partners. } \\
\text { Favour the formation of large OCs and to } \\
\text { reduce the formation of smaller OCs. }\end{array}$ & [69] \\
\hline $\begin{array}{l}\text { Src non-receptor tyrosine kinase } \\
\text { (c-Src) }\end{array}$ & $\square$ & $\begin{array}{l}\text { Maintains the dynamic organization of the ZLS. } \\
\text { Key to the formation of multinucleated OCs. }\end{array}$ & {$[22,73]$} \\
\hline $\begin{array}{l}\text { Human protein 'SH3 and PX domains 2A' } \\
\text { (Tsk5) }\end{array}$ & - & $\begin{array}{l}\text { Promotes the formation of podosomes and } \\
\text { fusion-competent protrusions. }\end{array}$ & [24] \\
\hline $\begin{array}{l}\text { C-C chemokine receptor type } 1 \\
\text { (CCR-1) }\end{array}$ & - & Key to the cell fusion. & [22] \\
\hline $\begin{array}{l}\text { Rapamycin-insensitive companion of TOR } \\
\text { (RICTOR) }\end{array}$ & - & $\begin{array}{l}\text { Regulates OCs fusion by } \\
\text { up-regulating DC-STAMP. }\end{array}$ & [23] \\
\hline Tenascin $x(\mathbf{T N X})$ & - & Suppresses OCs multinucleation. & [78] \\
\hline Dynamin & $\mathbf{\square}$ & Key to the formation of multinucleated OCs. & [79] \\
\hline Two-pore channel 2 (TPC2) & - & $\begin{array}{l}\text { Downstream effector of RANKL involved in } \\
\text { differentiation, multinucleation. }\end{array}$ & [80] \\
\hline $\begin{array}{l}\text { Fibronectin leucine-rich transmembrane } \\
\text { protein } 2 \text { (Flrt2) }\end{array}$ & घ & Key to the formation of multinucleated OCs. & [81] \\
\hline $\begin{array}{l}\text { Calcium release-activated channels } \\
\text { (CRAC-C channels) }\end{array}$ & - & Key to the formation of multinucleated OCs. & [82] \\
\hline $\begin{array}{l}\text { Transcription factor Spi-C } \\
\text { (SPIC) }\end{array}$ & - & $\begin{array}{l}\text { Governs both early and late stages of OCs } \\
\text { differentiation among which multinucleation } \\
\text { and bone-resorbing functions. }\end{array}$ & [83] \\
\hline $\begin{array}{l}\text { Crk-associated substrate } \\
\text { (Cas) }\end{array}$ & घ & $\begin{array}{l}\text { Key to actin cytoskeletal reorganization, actin } \\
\text { ring formation and multinucleation of OCs }\end{array}$ & [85] \\
\hline Luman & - & $\begin{array}{l}\text { Regulates the expression, localization and } \\
\text { stability of DC-STAMP. }\end{array}$ & [70] \\
\hline Vacuolar ATPase (ATP6v0d2) & $\mathbf{\square}$ & Key to the formation of multinucleated OCs. & [71] \\
\hline DAP-12 & $\square$ & $\begin{array}{l}\text { Key for acquiring fusion competence. } \\
\text { Key to the formation of multinucleated OCs. }\end{array}$ & [72] \\
\hline OSCAR-FcRy & - & Key for acquiring fusion competence. & [73] \\
\hline Transglutaminases & $\mathbf{\square}$ & Regulates migration and fusion of pre-OC. & [74] \\
\hline $\mathbf{P} 2 \times 7$ & - & $\begin{array}{l}\text { Key to the formation of multinucleated OCs } \\
\text { in vitro. }\end{array}$ & [75] \\
\hline $\mathbf{P} 2 \times 5$ & - & $\begin{array}{l}\text { Key to the formation of multinucleated OCs } \\
\text { in vitro. }\end{array}$ & {$[76,77]$} \\
\hline $\operatorname{miR124}$ & $\mathbf{\square}$ & Targets and inhibits Rab27a. & [67] \\
\hline
\end{tabular}




\subsection{OCs and Osteoclastogenesis during $O P$}

OP is one of the most severe bone disorders worldwide, affecting about 200 million patients [1], mainly in post-menopausal women and older people. The key feature of OP is a deterioration of the bone composition and subsequent bone fragility, leading to a severe risk of bone fractures [86]. OP has a multifactorial aetiology. Post-menopausal and senile forms of OP are the most common. They are caused by oestrogen loss and calcium deficiency with a critical role of the immune system in their physiopathology [87]. The secondary types of OP, which are triggered by diseases (such as RA, diabetes mellitus), use of drugs (such as glucocorticoids) and improper inhabits (such as nutritional deficiency, smoke etc.), and idiopathic juvenile OP are less widespread [88]. The uncoupling of bone resorption and bone formation (Figure 2) is the primary pathogenetic process in OP [89,90]. Biological mechanisms involved in this complex phenomenon are several and still partly unknown. Increased osteoclastogenesis and OCs lifespan and decreased osteoblastogenesis and OBs function occur in OP. Changes in local and systemic growth factors or hormones influence bone tissue. In specific, oestrogen contribute to the inhibition of OCs by reducing RANKL on marrow cells and increasing OPG secretion by OBs. Oestrogen increases the thiol antioxidants defences in OCs and suppress TNF- $\alpha$ [91]. During post-menopausal OP, oestrogen decline contributes to increasing RANKL secretion by OBs and osteocytes, which in turn increases bone resorption $[92,93]$.

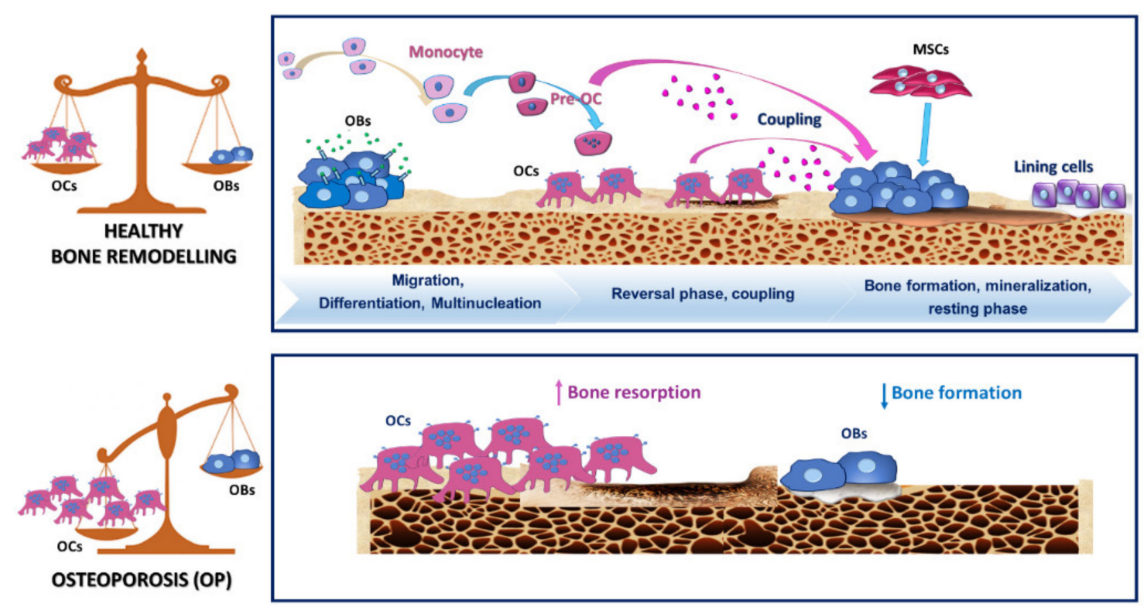

Figure 2. Graphical depiction of processes underpinning normal bone remodelling and osteoporosis (OP). The upper panel illustrates the classic phases occurring during normal bone remodelling, including migration of monocyte/macrophage precursors and differentiation towards osteoclasts precursors (pre-OCs) and mature multinucleated osteoclasts (OCs). Bone remodelling also requires a cross-talk between osteoblasts (OBs) and OCs to ensure a proper equilibrium between bone resorption and production. The lower panel describes the altered balance between bone resorption and formation in favour of bone resorption by OCs.

Interestingly, oestrogen plays an important role in modulating immune responses by controlling the functions of $\mathrm{T}$ cells and macrophages with essential implications in bone metabolism [94]. Oestrogen deficiency contributes to increasing inflammatory cytokines leading to increased osteoclastogenesis $[87,95]$. TNF- $\alpha$, produced by bone marrow T lymphocytes, is among the main cytokines in the oestrogen deficiency-induced bone loss [87]. In particular, it enhances OCs formation and increases the responsiveness of pre-OCs to RANKL thanks to Nuclear Factor kappa-light-chain-enhancer of activated B cell $(\mathrm{NF} \kappa \mathrm{B})$ and AP-1 signalling pathways. Moreover, it blocks osteoblastogenesis by impairing the function of bone-forming OBs [96]. The microbiota is among the factors activating $\mathrm{T}$ cells in sex steroid deficiency-associated bone loss during OP. Increased gut permeability contributes to triggering inflammatory signalling pathways [97]. Beyond T cells, B cells and macrophages also contribute to the production of osteoclastogenic cytokines $[96,98]$. 
Recently, the relationship between macrophage polarisation and oestrogen is gaining considerable attention among scientists. Several studies showed that oestrogen promote M2 macrophages (with a wound-healing phenotype) and inhibit M1 subset (with a pro-inflammatory phenotype). Oestrogen deficiency is responsible for an increased M1/M2 macrophage ratio, leading to increased production of osteoclastogenic factors. Oestrogen-dependent effects on macrophage subsets may be a potential target for pharmacological approaches in post-menopausal OP [99].

Oxidative stress also has a vital role in the pathophysiology of OP, leading to the production of ROS. ROS formation promotes the apoptosis of OBs and osteocytes in favour of osteoclastogenesis [100] and takes part also in OCs differentiation [100]. Excessive ROS production is among the most frequent pathological aspects of the skeletal involution following ageing and loss of sex steroids [101,102].

M-FM participates in the pathogenesis of a vast range of disorders; several inflammatory osteolysis diseases show excessive OC fusion and bone resorption [103]. It is still uncertain whether the alteration of M-FM is a phenotypical feature of OP. OCs in the bone resorption lesions of OP display elevated levels of CD9, a permissive fusogen [51]. Oestrogen concentration is essential in regulating some OCs-specific fusogenic molecules. A high concentration of oestrogen downregulates the expression of OC-STAMP, thus suggesting that oestrogen depletion during post-menopausal OP can increase OC-STAMP levels and multinucleation [104].

\subsection{Therapeutic Strategies in $O P$}

OCs are the primary target of bone sparing therapies due to their central role in physiologic bone development, remodelling and function. A better grasp of their intracellular signalling pathways can be helpful to find novel therapeutic targets. In the past, oestrogen replacement (ER) was the most used therapy, given that oestrogens directly contribute to OCs inhibition $[105,106]$. Although ER and selective oestrogen receptor modulators reduce the incidence of OP-related fractures, their use generates several side effects $[107,108]$. Along this line, experts have examined several alternatives to both neutralise bone destruction and favour anabolic processes (Figure 3). Nowadays, the first-line regimens for OP are bisphosphonates (BPs), which are anti-resorptive treatments. BPs bind avidly to hydroxyapatite crystals on bone surfaces $[109,110]$ and are up-taken by OCs during the bone resorption [111]. BPs are divided into two classes with different mechanisms of action. Non-amino-BPs cause OCs apoptosis. Amino-BPs cause changes in OCs cytoskeleton, leading to impaired OCs function [112]. Despite their excellent results in reducing risk fractures [113], BPs cannot rebuild the injured bone architecture [114] and show several side effects. Long-term use of BPs compromises bone strength because of (i) unintended inhibition of coupled bone formation; (ii) impairment in the bone remodelling; and (iii) decrease in the OBs number and bone formation rate [115]; thereby, contributing to low bone repair ability [116-118]. Several efforts in finding new classes of anti-resorptive treatments are ongoing. Among the most promising alternatives, Denosumab, a monoclonal antibody to RANKL, blocks OCs maturation, function and survival, thus reducing bone resorption and risk fractures [119-121]. It is not incorporated into the bone matrix-like BPs, and bone turnover is not suppressed after its cessation; thus, continuous administration sustains its biological activity [122]. Using anabolic agents has gained growing interest among scientists for their ability to promote bone formation through the activation of OBs. Treatments with parathyroid hormone (PTH), PTH analogues and sclerostin inhibitors (such as the sclerostin monoclonal antibody romosozumab) are regimen treatments to encourage bone anabolism [123-125]. They effectively reverse bone damages in OP by restoring the structure of trabecular and cortical bone. However, these anabolic treatments are used for a limited time due to several side effects [126] and their incapacity to prevent bone resorption; thus, patients should always receive anti-resorptive agents to increase bone mineral density gain [127]. Identifying novel classes of remedies capable of "uncoupling" bone resorption from the bone formation by favouring the latter is highly demanding. In this line, strontium ranelate inhibits OCs function while promoting OBs proliferation, by uncoupling bone formation and bone resorption but shows several side effects [128]. Selective inhibitors of osteoclastic hydrogen ion transport and CTSK are 
among the newer techniques for inhibiting bone resorption [129-131]. They remove active OCs without impairing OCs differentiation, which is crucial to ensure proper OCs-OBs coupling during bone remodelling. While CTSK inhibitors present several safety concerns, V-ATPase efficacy and safety remain undefined, [131].

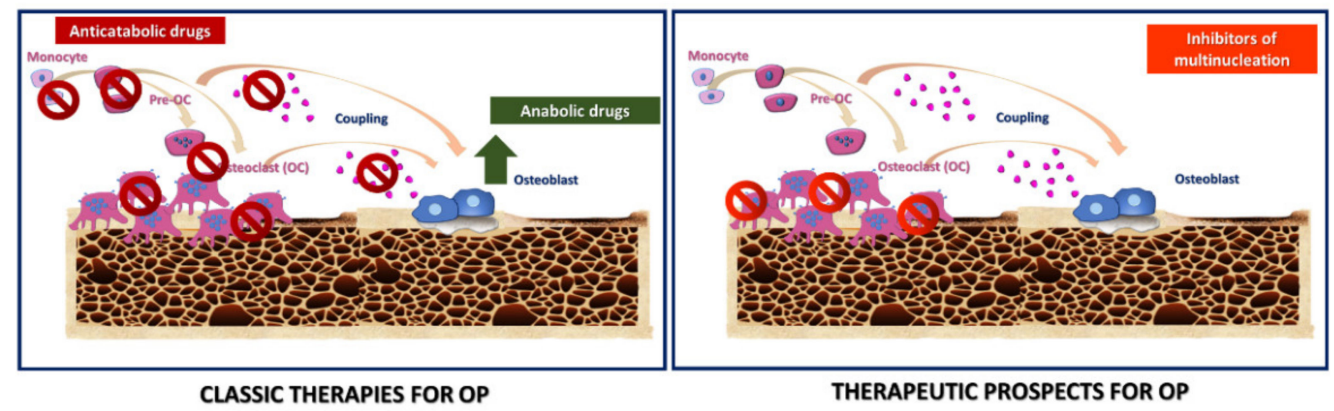

Figure 3. Graphical representation of classic and new therapeutic prospects for OP. The left panel illustrates standard remedies for OP, divided into two classes: anti-catabolic and anabolic drugs. The first class inhibits bone resorption by targeting either the differentiation, resorptive function, cytokines production by osteoclasts (OCs). The second class builds up bone architecture, stimulating osteoblasts (OBs) and their precursors. The right panel outlines new therapeutic prospects for OP. It refers to inhibitors of multinucleation, which would preserve the OCs precursors to support the OCs-OBs coupling.

Novel Targets for Anti-Osteoclastogenic Therapies for OP

Targeting both bone resorption and M-FM selectively could represent a strategic alternative to reduce OCs functions while preserving OBs-OCs communication. In this light, therapeutic options based on natural compounds could act on specific phases of OCs formation like fusion and multinucleation. In the past few years, different families of nutraceuticals showed inhibitory effects on OCs differentiation and bone resorption [132,133]. Although they inhibit critical genes related to OCs cell-cell fusion (DC-STAMP, ATP6v0d2, OC-STAMP) and alter the creation of the actin ring, they do not inhibit in a specific manner M-FM. Besides natural compounds [133], other molecules like miRNA can specifically inhibit M-FM and fusion. In specific, miR7b, miR30a target the unique OCs-specific fusogen DC-STAMP [37,134]; miR26a targets CTGF/CCN2 and inhibits DC-STAMP [66]; miR124 targets Rab27a [67]. Inhibiting DC-STAMP can provide both decreased OCs activity and enhanced bone production by OBs, leading to increased bone mass [117]. The overexpression of miR7b, miR26a, miR30a in pre-OCs can inhibit OCs multinucleation, actin-ring formation, and bone resorption $[37,66,135]$; therefore suggesting their potential use for inhibiting M-FM in vivo. Recently, a polyethylenimine (PEI) functionalised graphene oxide complex loaded with miR-7b overexpression plasmid has been tested in ovariectomised (OVX) mice. Herein, miR-7b overexpression abrogated OCs fusion and bone resorption while maintaining mononuclear preOCs [134]. This research provides preliminary evidence on the in vivo potential of specific miRNAs to target M-FM in OP. Developing anti-DC-STAMP and anti-OC-STAMP antibodies is another attempt to block OCs fusogenic function with encouraging in vitro results in suppressing OCs multinucleation $[44,136]$. To date, no indications are available whether they can modulate $\mathrm{OP}$ in vivo.

Blocking Siglec-15 and Rab27a offers further promising opportunities to prevent bone loss and increase bone mass. Blockage of Siglec-15 is highly specific, given that its expression is highly OCs specific. Siglec-15 neutralising antibody induces a rapid internalization of Siglec-15 and inhibits in vitro OCs differentiation, and M-FM in mouse and human bone marrow monocyte/macrophage (BMM) cells stimulated with RANKL [60]. Siglec-15 antibody induce increased bone mineral density in young mice $[59,63]$ and protected against glucocorticoid-induced OP of growing skeleton in juvenile rats [137]. Furthermore, it has been proposed as an effective treatment for juvenile OP [60], as it increases bone 
mass without any adverse effects on skeletal growth [138]. The unique property of the anti-Siglec-15 $\mathrm{Ab}$ of inhibiting M-FM in secondary but not in primary spongiosa can probably depend on a collagen II-OSCAR-dependent compensatory signalling for Siglec-15 inhibition in the primary but not in the secondary spongiosa [138]. miR-124 targets Rab27a and inhibits M-FM, therefore rising its potential use for OP [67]. Although these inhibitors of multinucleation hold good promises as therapeutics for OP (Table 2), clinical trials are mandatory to validate their efficacy, safety and their potential superiority to current drugs.

Table 2. Perspectives for osteoporosis (OP) therapy: biological targets for selective inhibition of monocyte-macrophage fusion and multinucleation (M-FM) in osteoclasts (OCs).

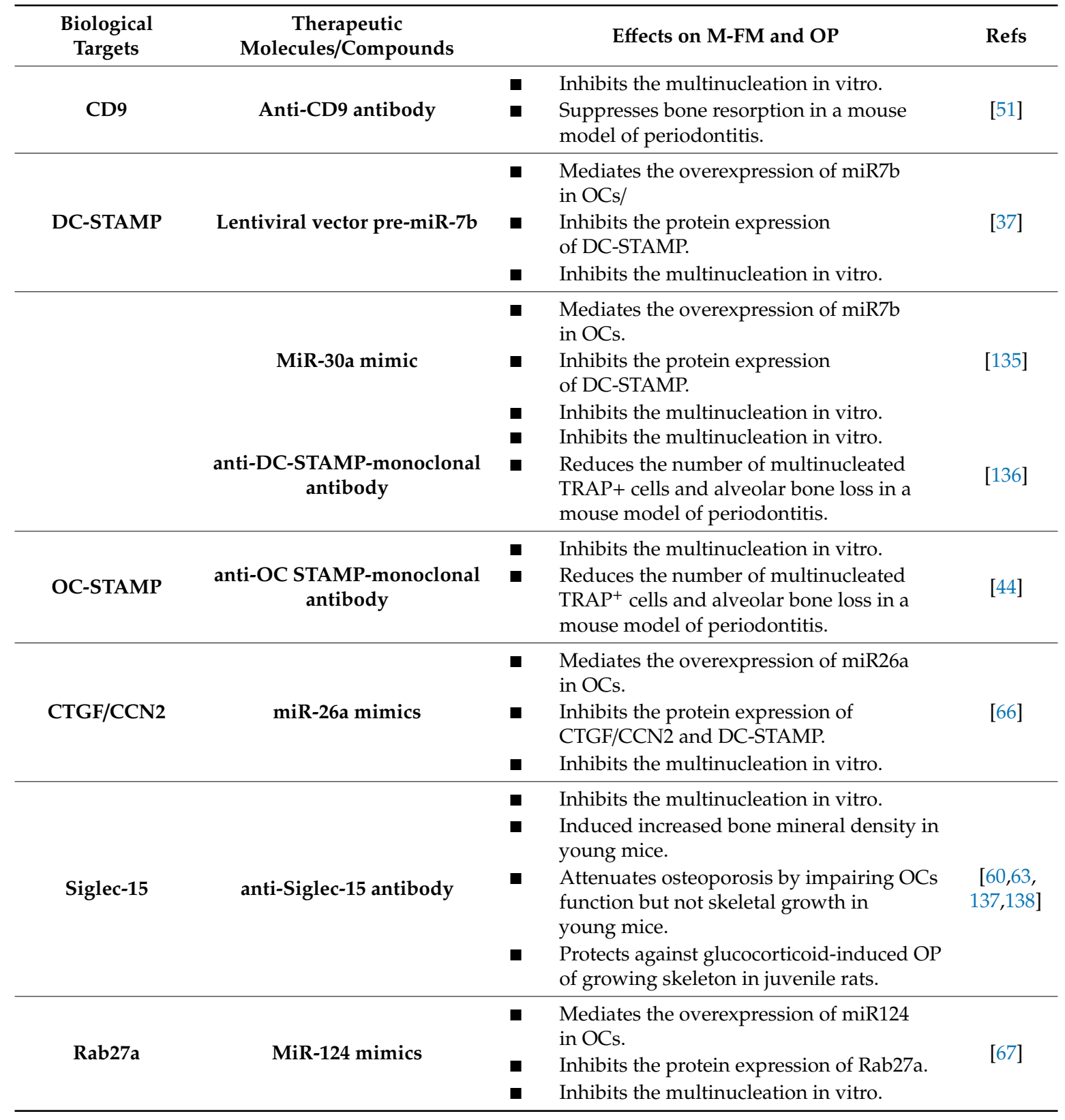

\section{GCs and OCs in RA: Relationships with Bone Erosion and Therapeutic Alternatives}

\subsection{Leading Characteristics of GCs: Similarities and Differences with OCs}

GCs are multinucleated polykarions macrophages (up to 100-200 nuclei) that likely OCs originate from monocyte-macrophage lineage and cover essential roles in a variety of processes, including 
foreign body reactions, infections and inflammatory disorders [14,139]. GCs formation seems to be an adaptation process for enhancing phagocytic activity when macrophages cannot degrade large biomaterials or tissue irritants [12,140]. Insults during RA like dysregulated immunity and cytokine network and enhanced chondrocyte/OCs activation contribute to inducing macrophage fusion and GCs formation [141]. Depending on the fusion area, organelles arrangement and cytokines, three classes of GCs, with distinct histological features, can form Langhans giant cells (LGCs), Touton giant cells (TGCs), and foreign body giant cells (FBGCs) [7,14]. In particular, Interferon gamma (IFN- $\gamma$ ) and IL-13 induce LGCs, which display nuclei surrounding the Golgi apparatus and other organelles. They mainly exhibit an inflammatory phenotype with implications during granulomas and RA [139]. M-CSF, Interleukin 6 (IL-6), and IFN- $\gamma$ promote TGCs in many pathologic processes, such as xanthomas and granulomas [14]. IL-4 and IL-13 stimulate FBGCs, which counteract the inflammatory responses [142]. GCs, unlike OCs, cannot resorb bone and express several M2 markers like Ym1, Fizz1, CD-206, arginase-1 and arachidonate 15-lipoxygenase (Alox 15), an enzyme required in wound-healing and termination of inflammation [143]. Overall, GCs are found in several anatomical sites such as cartilage and the synovial membrane in RA patients. Authors showed a strong correlation between GCs and synovitis severity together with an enhanced OCs number in the bone [15].

Differently from OCs, GCs cannot create lacunar pits of resorption in the bone [15]; they adhere to the bone and reduces the mineral phase without digesting the matrix fraction [7]. GCs express CD-11c, CD-68, HLA-DR, and DC-sign like dendritic cells and can select lymphocyte co-stimulatory molecules [15], thus displaying an active role during antigen presentation. GCs and OCs display different integrins for the fusion among cell types. GCs precursors exhibit the integrins $\alpha \beta 2$, whereas $\alpha \beta 3$ mediates OCs fusion and cytoskeleton rearrangement [7]. GCs express higher levels of CCL2, CCL3, CCL4, CCL5, CCL9, and GM-CSFR when compared to OCs [15]. CCL-2 and its receptor CCR2 are essential mediators which foster the chemotaxis of both OCs and GCs before cell fusion [15]. The knowledge of fusion mechanisms and modulators driving the differentiation of monocyte-macrophage precursors towards OCs and GCs is not well defined [139]. RANKL and the cytokines IL-4 and IL-13 are among the leading cell-type-specific fusion mediators in OCs and GCs [7]. Macrophage fusion receptor (MFR), also known as P84/BIT/SIRP $\alpha /$ SHPS-1, is transiently expressed in macrophages at the onset of fusion by stimulating the differentiation of both OCs and GCs [144]. MFR belongs to the superfamily of immunoglobulins and interacts with CD47 on fusing macrophages [145]. OC-STAMP and DC-STAMP, induced by RANKL-NFATc1 axis, are essential mediators in both OCs and GCs to favour cell fusion. Despite both GCs and OCs that occur following cell fusion in a DC-STAMP-dependent manner, the regulating fusion competency is different. GCs display PU.1 and NF-kB mobilisation to the DC-STAMP promoter in GCs, while OCs show c-Fos and NFATc1 recruitment to the DC-STAMP promoter. c-Fos-deficient mice exhibit several GCs along with DC-STAMP activation. In contrast, DC-STAMP ${ }^{-/}$mice did not show GCs formation [146]. RANKL and ITAM cooperate by inducing NFATc1 during OCs formation but not in GCs; whereas IL-4 and IL-13 mediate GCs formation but not OCs through the activation of signal transducer and activator of transcription 6 (STAT6) via the binding with E-cadherin [146-148]. E-cadherin is also crucial for macrophage fusion and multinucleation for the formation of mature OCs [149]. However, OCs and GCs share several common prefusion mediators, including M-CSF, DAP-12, triggering receptor expressed by myeloid cells 2 (TREM2), purinergic receptor P2X7 (P2RX7), tumour necrosis factor (TNF) and potassium calcium-activated channel subfamily $\mathrm{N}$ member 4 (KCNN4) [7]. TNF promotes multinucleation in both OCs and GCs. Its combination with RANKL can act on pre-OCs to promote NFATc1-dependent OCs and M-FM through the activation of c-Jun N-terminal kinase (JNK) pathway. KCNN4 takes part at the onset of fusion, and it is necessary for OCs and GCs formation in rodents and humans, by regulating $\mathrm{Ca}^{2+}$ signalling [6]. Monocyte subsets display a distinct pattern of tetraspanins (CD-9, CD81) expression and different capacities to form GCs. The intermediate subset $\mathrm{CD} 14^{++} \mathrm{CD} 16^{+}$of peripheral human monocytes fuse faster and produce larger GCs than the other subsets. Although tetraspanins would seem to play an important role in the fusion of intermediate monocytes, the regulation of 
GCs formation has to be still clarified [150]. Similarly to OCs, miRNAs can regulate macrophage fusion towards GCs. MiR7-a-1 regulates GCs formation by targeting Tm7sf4, which is a fusogenic cell surface [151]. Finally, TRAP, CTSK, and MMP-9, expressed during bone resorption, are OCs specific and detected at low concentrations, or not at all, in GCs [7].

\subsection{M-FM of OCs and GCs and Osteoclastogenesis during Inflammation}

Recently, there has been a growing interest in elucidating the influence of the inflammatory milieu on the differentiation of monocyte-macrophage precursors into multinucleated OCs and GCs $[16,152,153]$. In particular, macrophages can mainly display two main cell subsets with inflammatory (M1) and alternative wound-healing (M2) phenotypes [154]. During chronic inflammation like RA, macrophages display mainly a pro-inflammatory M1 phenotype (markers CD-80, CD-86, TRL2, TRL4, i-NOS) and release inflammatory cytokines such as TNF- $\alpha$, IL-1 $\beta$, IL-6, IL-15, IL-17, IL-23, and IL-34. During wound-healing and repair processes, macrophages show an alternative M2 phenotype (markers CD-206, CD-209, CD-163, FIZZ1, and Ym1/2) and release anti-inflammatory cytokines such as IL-10, IL-1R antagonist, vascular endothelial growth factor (VEGF), IL-33. M2 activation status can, in turn, display heterogeneous and distinct macrophages subtypes: M2a, M2b, M2c, M2d depending on the stimuli [155]. Miyamoto T et al. showed that OCs exhibit similar behaviour of M1 macrophages under inflammatory conditions, whereas GCs display mainly an M2-like phenotype [50]. M1 macrophages would seem the leading players which modulate fusion events of pre-OC towards mature OCs by up-regulating fusogenic molecules such as CD-40, DC-STAMP, E-cadherin, MFR-CD47, and MR [144]. TRAF6 would seem to modulate the polarisation of M1 OCs and M2 GCs during inflammation, thus opening valuable insights for future therapeutic applications $[146,156]$. Signal transducer and activator of transcription (STAT) signalling pathway plays a pivotal role in modulating macrophage polarization. Among STAT family molecules, STAT-6 contributes to favouring the formation of FBGCs through the promotion of macrophage cell-cell fusion. Conversely, STAT-1 is an inhibitor of FBGCs multinucleation [148]. In general, the STAT-1/STAT- 6 axis modulates MF via the regulation of OC-STAMP and DC-STAMP and modulates fusogenic mechanisms in FBGCs [7] (Figure 4). The anti-inflammatory cytokines, released from M2 macrophages, inhibit osteoclastogenesis and promote Th2 profile and GCs formation $[15,92,157,158]$. In particular, M2a fusion under the presence of E-Cadherin, DC-STAMP and MR produce FBGCs. $\mathrm{M} 2 \mathrm{~b} \lambda$ fusion form GCs during tuberculosis thanks to MR and other potential fusogens like TLR and MyD88. M2d fusion under not well-defined fusogenic molecules favours the formation of TGCs [139]. Conversely, the inflammatory mediators secreted by M1 macrophages mainly display an osteoclastogenic potential. They can substitute RANKL activity by promoting Th1/Th17 profile and OCs formation, thereby deregulating bone remodelling $[7,15,159,160]$. In particular, these cytokines support pre-OCs recruitment to the bone microenvironment and their differentiation into OCs [161]. Moreover, they contribute to generating LGCs, often detected in chronic inflammatory disorders like RA [139]. Among inflammatory mediators, TNF- $\alpha$ is a potent inflammatory inducer of bone resorption. TNF- $\alpha$, in synergy with RANKL, can activate excessive osteoclastogenesis and bone resorption. It enhances RANK expression on OCs precursors and M-CSF and RANKL in OBs and synovial fibroblasts [159]. In RA, TNF- $\alpha$ also acts on synovial cells by stimulating IL-34, NF- $K B$ and JNK signalling [162]. IL-1 $\beta$ is another osteoclastogenic cytokine, which directly stimulates OCs differentiation under sufficient levels of RANKL. IL-1 $\beta$ can still foster the differentiation of pre-OCs by enhancing TNF- $\alpha$-induced osteoclastogenesis and RANKL expression [15]. Interestingly, IL-1 $\beta$ can promote distinct processes of multinucleation of bone marrow OCs precursors. Following IL- $1 \beta$ stimulation, CD-31 $1^{+}$Ly- $6 \mathrm{C}^{+}$ myeloid blasts show the fast production of OCs ( $>20$ nuclei) with a top-level of bone resorption and shortened lifespan. CD-31-, Ly-6 Chi monocytes display a lower number of OCs formation when compared to CD-31+ Ly-6C+ myeloid blasts but higher life span [163]. IL-1 $\beta$ supports most large OCs by increasing cyclin D in early blast cultures [163]. Interleukin-1 receptor-associated kinase 4 (IRAK4) is a protein kinase, which transduces signals from inflammatory cytokines and toll-like receptors by 
stimulating natural killer cells, antigen-presenting cells and T-cells [143]. In inflammatory conditions like IL-1 $\beta$ stimulation, IRAK-deficient cells display reduced osteoclastogenesis and enhanced GCs formation [143]. In this light, IRAK-4 might be a therapeutic target to modulate M1/M2 polarisation by antagonising inflammatory osteolysis. Using a system genetic approach, Behmoaras J et al. identified a trans-regulated multinucleation network in macrophages with a critical role of KCNN4 in bone homeostasis and inflammatory disorders [6]. KCNN4 regulates $\mathrm{Ca}^{2+}$ signalling during macrophage multinucleation. $\mathrm{KCNN}^{-/-}$mice with collagen antibody-induced arthritis (CAIA) model showed reduced joint inflammation, tissue damage and serum bone resorption markers without affecting OBs activity; thus, opening fascinating insights to prevent inflammation-related bone loss [6]. Over the last years, there has been an increasing awareness that mononuclear phagocytes display receptors for extracellular nucleotides, which modulate inflammatory responses. P2RX purinergic receptors belong to this subfamily and bind to the extracellular adenosine 5 '-triphosphate (ATP). P2RX7 promotes several physiologic and pathologic conditions, including the multinucleation of monocyte-derived human macrophages [164]. Macrophages with high levels of P2RX7 are more prone to form GCs rather than OCs [165]. P2RX7 contributes to activating the inflammasome in both OCs and GCs. P2RX7 favours the release of IL-1 $\beta$ and IL-18 and the synthesis of ROS with essential implications in caspase activation and apoptosis induction [166]. Similarly, P2RX5 promotes OCs-mediated inflammatory bone loss and hyper-multinucleation of OCs [77]. During inflammatory conditions, P2RX5 $5^{--}$mice display bone loss because of the P2RX5-mediated inflammasome activation and IL-1 $\beta$ production, important for OC maturation [77]. Interestingly, several miRNA, including miR-9, miR-127, miR-155 and miR-125b would seem implicated in promoting the activation of M1 macrophages and pro-inflammatory responses by targeting several adaptor proteins and transcription factors [167] (Table 3).

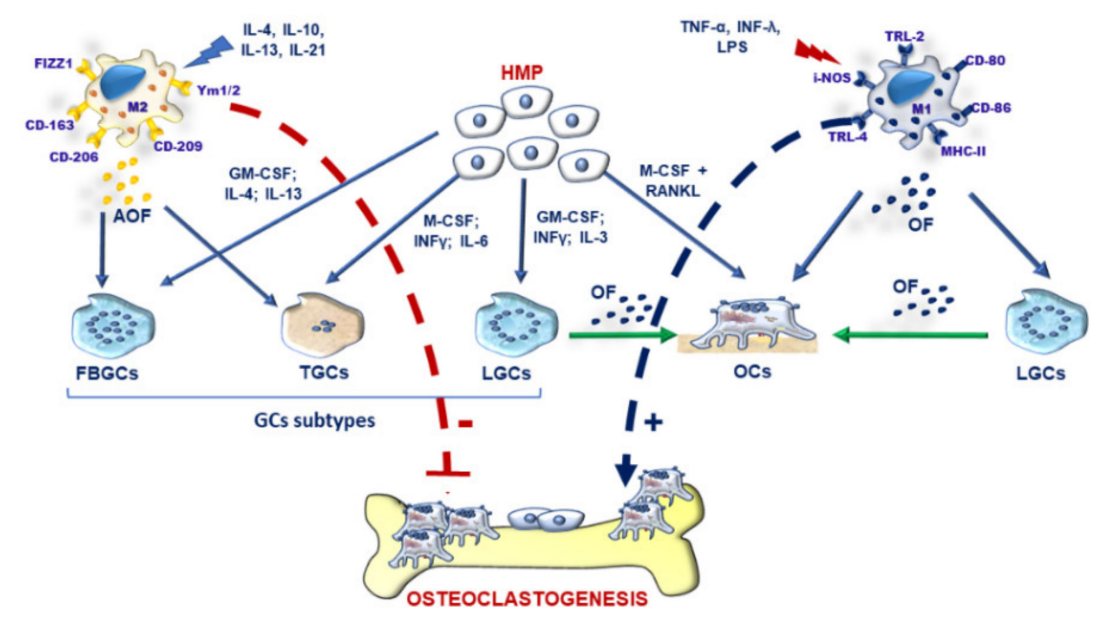

Figure 4. Graphical representation of factors modulating osteoclasts (OCs) and giant cells (GCs) formation. M2 macrophages, induced by IL-4, IL-10, IL-13 and IL-21, can release anti-osteoclastogenic factors (AOF), which promote foreign-body giant cells (FBGCs) and Touton giant cells (TGCs). Hematopoietic monocyte/macrophages precursors (HMP) under (i) GM-CSF, IL-4 and IL-13 can originate FBGCs; (ii) M-CSF, INF- $\gamma$, and IL-6 stimuli can induce Touton cells (TGCs); and (iii) GM-CSF, INF- $\gamma$ and IL-3 can produce Langhans giant cells (LGCs). FBGCs, TGCs and LGCs represent the main three subtypes of GCs, displaying distinct histological and functional features. HMP can originate mature OCs after M-CSF and RANKL stimulation. M1 macrophage, induced by TNF- $\alpha$, LPS and INF- $\lambda$, release osteoclastogenic factors (OF), which promote OCs and LGCs. LGCs can release OF, which in turn support the OCs differentiation. M2 macrophages inhibit osteoclastogenesis by releasing AOF (red arrow). M1 macrophages promote osteoclastogenesis via the release of (blue arrow). 
Table 3. Biological targets involved in monocyte-macrophages fusion and multinucleation (M-FM) during the inflammatory bone loss.

\begin{tabular}{|c|c|c|}
\hline Biological Target & $\begin{array}{l}\text { Effects on M-FM and } \\
\text { Inflammatory Bone Loss }\end{array}$ & Refs \\
\hline $\begin{array}{l}\text { Macrophage fusion receptor } \\
\text { (MFR) }\end{array}$ & $\begin{array}{l}\text { - Promotes macrophage fusion. } \\
\text { - Promotes the differentiation of OCs and GCs. }\end{array}$ & {$[144,145]$} \\
\hline $\begin{array}{l}\text { Potassium calcium-activated } \\
\text { channel subfamily N member } 4 \\
\text { (KCNN4) }\end{array}$ & $\begin{array}{l}\text { Favours the macrophage fusion and } \\
\text { multinucleation in bone homeostasis and } \\
\text { inflammatory disorders. } \\
\text { - Promotes the differentiation of OCs and GCs. }\end{array}$ & [6] \\
\hline $\begin{array}{c}\text { Tetraspanins } \\
\text { (CD-9, CD81, CD63, CD53) }\end{array}$ & $\begin{array}{l}\text { - Promote monocyte/macrophage fusion. } \\
\text { - Release several osteoclastogenic cytokines. } \\
\text { - Promote the fusion of pre-OC towards } \\
\text { mature OCs. }\end{array}$ & [150] \\
\hline $\begin{array}{l}\text { Pro-inflammatory macrophages } \\
\text { (M1) }\end{array}$ & $\begin{array}{l}\text { - Promotes osteoclastogenesis through the } \\
\text { release of osteoclastogenic cytokines. } \\
\text { - Promotes the induction of Th1/Th7 profile. } \\
\text { Promotes the formation of Langherans giant } \\
\text { cells (LGCs). } \\
\text { - Favours the production of reactive oxygen } \\
\text { species (ROS). }\end{array}$ & {$[15,98,152,153]$} \\
\hline $\begin{array}{l}\text { Interleukin-1 beta } \\
\quad(\text { IL-1 } \beta)\end{array}$ & $\begin{array}{l}\text { - Promotes the multinucleation of OCs and GCs } \\
\text { - Favours the differentiation and maturation of } \\
\text { large OCs. } \\
\text { - Promotes the pre-OCs differentiation via } \\
\text { TNF- } \alpha \text {-induced osteoclastogenesis. } \\
\text { - Promotes the multinucleation of bone } \\
\text { marrow precursors. }\end{array}$ & {$[7,163]$} \\
\hline $\begin{array}{l}\text { Tumour necrosis factor-alpha } \\
\qquad(\text { TNF- } \alpha)\end{array}$ & $\begin{array}{l}\text { - Promotes osteoclastogenesis. } \\
\text { - Promotes in synergy with RANKL excessive } \\
\text { osteoclastogenesis and bone resorption. } \\
\text { Fosters RANKL and M-CSF in synovial } \\
\text { fibroblasts and osteoblasts. }\end{array}$ & [159] \\
\hline $\begin{array}{l}\text { Interleukin } 6 \\
\quad(\text { IL-6) }\end{array}$ & $\begin{array}{l}\text { - Stimulates OCs maturation. } \\
\text { - Promotes vascular endothelial growth factor } \\
\text { (VEGF)-stimulated pannus proliferation. } \\
\text { - Promotes synovitis and joint destruction. } \\
\text { - Promotes B-cell maturation and } \\
\text { TH-17 differentiation. }\end{array}$ & {$[152,158]$} \\
\hline $\begin{array}{l}\text { Signal transducer and activator of } \\
\text { transcription-6/-1 axis } \\
\text { (STAT-6/STAT-1 axis) }\end{array}$ & $\begin{array}{ll}\text { - } & \text { Regulates OC-STAMP and DC-STAMP. } \\
\text { - } & \text { Regulates fusogenic mechanisms in FBGCs. }\end{array}$ & {$[7,148]$} \\
\hline $\begin{array}{l}\text { Tumour necrosis factor } \\
\text { receptor-associated factor } 6 \\
\text { (TRAF6) }\end{array}$ & $\begin{array}{l}\text { - Regulates inflammatory responses. } \\
\text { - Regulates the differentiation of various } \\
\text { immune cells. } \\
\text { - Promotes the macrophage polarization into } \\
\text { M2 subset. }\end{array}$ & {$[156,160]$} \\
\hline $\begin{array}{l}\text { Interleukin-1 receptor-associated } \\
\text { kinase } 4 \\
\text { (IRAK4) }\end{array}$ & $\begin{array}{l}\text { IRAK-deficient cells display reduced } \\
\text { osteoclastogenesis and enhanced } \\
\text { GCs formation. }\end{array}$ & [143] \\
\hline
\end{tabular}


Table 3. Cont.

\begin{tabular}{|c|c|c|}
\hline Biological Target & $\begin{array}{l}\text { Effects on M-FM and } \\
\text { Inflammatory Bone Loss }\end{array}$ & Refs \\
\hline $\begin{array}{l}\text { Purinergic receptor P2X7 } \\
\text { (P2RX7) }\end{array}$ & $\begin{array}{l}\text { Promotes the multinucleation of } \\
\text { monocyte-derived human macrophages. } \\
\text { - Activates the inflammasome in both OCs } \\
\text { and GCs. } \\
\text { Promotes the release of inflammatory and } \\
\text { ROS molecules. }\end{array}$ & [164-166] \\
\hline $\begin{array}{l}\text { Purinergic receptor P2X5 } \\
\text { (P2RX5) }\end{array}$ & $\begin{array}{l}\text { - Promotes OCs-mediated inflammatory } \\
\text { bone loss. } \\
\text { - Promotes hyper-multinucleation of OCs. } \\
\text { - Promotes inflammasome activation and IL-1 } \\
\beta \text { production. }\end{array}$ & [76] \\
\hline $\begin{array}{l}\text { Mammalian target of rapamycin } \\
\text { (mTOR) complex } 1 \text { (mTORC1) }\end{array}$ & $\begin{array}{l}\text { - Activates the autophagy. } \\
\text { Is implicated in regulating bone resorption and } \\
\text { homeostasis in pathologic conditions. }\end{array}$ & {$[23,101]$} \\
\hline miR9 & $\begin{array}{l}\text { Promotes M1 polarization through targeting } \\
\text { the peroxisome proliferator-activated receptor } \\
\delta(\text { PPAR } \delta) \text {. } \\
\text { Overexpression of mir9 prevents the BCL-6- } \\
\text { mediated anti-inflammatory effects. }\end{array}$ & [167] \\
\hline $\operatorname{miR127}$ & $\begin{array}{l}\text { - Is prominently induced upon toll-like receptor } \\
\text { (TLR) engagement. } \\
\text { Enhances the activation of JNK Kinase and the } \\
\text { development of M1 macrophages. } \\
\text { - Promotes the production of } \\
\text { pro-inflammatory cytokines. }\end{array}$ & [167] \\
\hline $\operatorname{miR} 125 b$ & $\begin{array}{l}\text { - Promotes the formation of M1 macrophages. } \\
\text { - Promotes pro-inflammatory responses. }\end{array}$ & [167] \\
\hline $\operatorname{miR} 155$ & $\begin{array}{ll}\text { - } & \text { Targets IL- } 13 \text { receptor } \alpha 1 . \\
\text { - } & \text { Inhibits STAT-6 activation. } \\
\text { - } & \text { Promotes M1 polarisation. }\end{array}$ & [167] \\
\hline Dysbiosis & $\begin{array}{l}\text { - Impairs immune response. } \\
\text { - Promotes various pro-inflammatory } \\
\text { signalling pathways. }\end{array}$ & [97] \\
\hline
\end{tabular}

\subsection{Pathological Features of $R A$}

RA is one of the most widespread chronic inflammatory and autoimmune illnesses with a tremendous impact on patients quality life, leading to joint swelling, pain, and destruction [168]. Risk factors include genetic determinants (e.g., MHC class II genes, HLA-DR1, HLA-DR2, HLA-DRB1), smoking, obesity, infections [169,170] and female gender (with a two-fold increase risk than male) [171]. Being an autoimmune disorder, RA patients display an excessive immune response of T-cells, leading to the formation of autoantibodies. Th17 cells are a pro-osteoclastogenic T-cell subset, markedly activated than Treg with a critical functional role in inflammation. In particular, Th17 cells activate several immune cells and foster OCs activity by inducing RANKL in synovial fibroblasts [168]. This excessive immune response leads to high expression of rheumatoid factor (RF) and anti-citrullinated protein antibodies (ACPAs), considered as a powerful predictor of bone erosion [172]. ACPAs are the most specific biomarker found in RA serum, capable of mediating bone loss $[5,173,174]$.

The inflamed synovial membrane, characterised by the presence of T cells, synovial fibroblasts, activated macrophages and excessive angiogenesis processes, is a typical feature in RA patients, which culminates in joint destruction [175]. Activated T cells and arthritic synovial fibroblasts provide 
alternative sources of RANKL throughout the synovial lining layer near sites of bone erosion [176]. Increased RANKL mRNA and protein expression in the synovium and lowered expression of OPG occur in RA patients. The altered RANKL/OPG ratio at the pannus-bone interface contribute to supporting focal lesions in RA; thus representing a potential target for therapeutic intervention [161]. In RA synovium, macrophages play a pivotal role in feeding the inflammatory network [152]. The percentage of pro-inflammatory M1 is higher than M2 subset due to the excessive activation, synovial proliferation and enhanced anti-apoptotic activities [152]. The newly inflammatory milieu plays a pivotal role in promoting resorption activities and reducing bone formation. In this light, TFN- $\alpha$ and IL-1 $\beta$ modulate pre-OCs recruitment to the inflamed sites and their differentiation into OCs and inhibit OBs differentiation [161]. Inhibitors like DKK1, DKK3, sFRP1, sFRP2, and sFRP4 impair bone formation at erosion sites leading to reduced canonical wingless (Wnt) pathway, crucial for bone deposition, development and remodelling [161]. Beyond activated macrophages, RA synovium displays distinct patterns of GCs subtypes, including LGCs and TRAP ${ }^{+} / \mathrm{CTSK}^{-}$FBGCs. Such cells can play several roles, including antigen presentation and promotion of OCs differentiation [15]. Local accumulation of TRAP ${ }^{+}$ and CTSK ${ }^{+}$OCs in the articular joint triggers erosion processes on both bone and articular cartilage [15] (Figure 5). Besides activating inflammatory and catabolic pathways, the cytokine "storm" impairs oxidant/antioxidant balance in joint tissues, which is another hallmark of the disease responsible for tissue destruction $[177,178]$. RA patients display a five-fold increase in mitochondrial ROS production in whole blood and monocytes when compared to healthy subject [179]. M1 macrophages produce high levels of ATP and ROS because of excessive glucose uptake [152]. Another factor recently implicated in the pathogenesis of RA is the deregulation of the autophagic pathway, a pro-survival mechanism responsible for cell responses following injury. The mammalian target of rapamycin (mTOR) complex 1 (mTORC1) activates the autophagy mechanism. In RA, its impairment promotes (i) osteoclastogenesis; (ii) the survival of inflammatory cells, and (iii) the generation of citrullinated peptides [180]. Autophagy also participates in the reduction of ROS through the elimination of damaged mitochondria to prevent apoptosis [181].

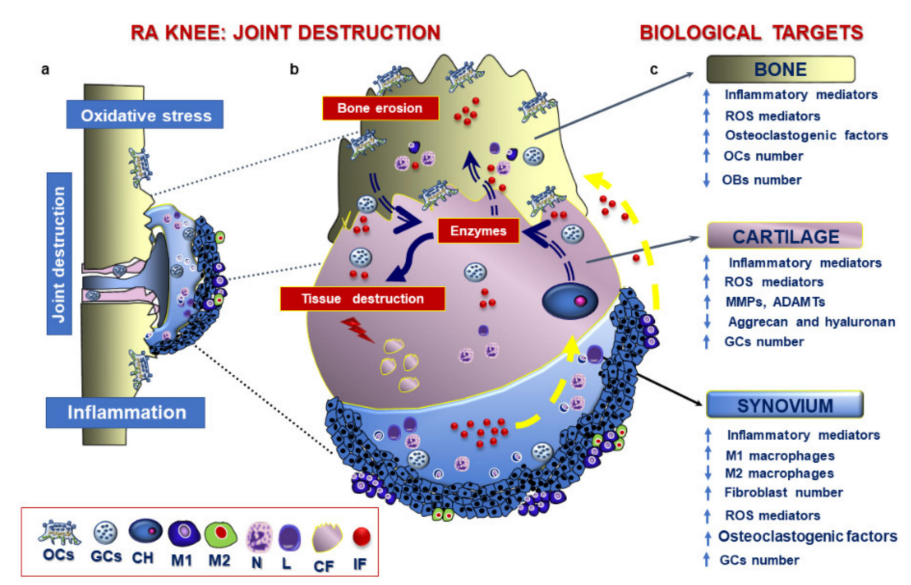

Figure 5. Graphical representation of processes in RA knee and potential biological targets. (a) RA displays inflammatory, catabolic and oxidative processes in the synovial membrane, subchondral bone and articular cartilage. (b) A high-magnification view of processes implicated in joint destruction. Synovial membrane displays hyperplasia of the lining layer and marked activation of neutrophils, lymphocytes and M1 macrophages, which release inflammatory factors (IF). The phlogistic environment in the synovial membrane (yellow arrow) fosters the release of several matrix-degrading enzymes by chondrocytes $(\mathrm{CH})$ and the release of osteoclastogenic cytokines by giant cells (GCs). These factors trigger the destruction of both bone and cartilage fragments (CF). The inflammatory milieu still fed by GCs amplify this vicious circuit (c) List of main biological targets in the bone, cartilage and synovium. OCs: osteoclasts; GCs: giant cells; $\mathrm{CH}$ : chondrocytes; M1: M1 macrophages; M2: M2 macrophages; $\mathrm{N}$ : neutrophils; L: lymphocytes; CF: cartilage fragments; IF: inflammatory factors. 


\subsection{Therapeutic Strategies in $R A$}

Identifying potential new therapeutic candidates for RA is a challenge among clinicians because of the multi-coloured clinical scenario of patients presenting structural and functional joint alterations and many systemic effects [177]. Despite their promising clinical outcomes, the use of anti-resorptive drugs targeting OCs is inadequate [182]. Currently, disease-modifying anti-rheumatic drugs (DMARDs) are among the first-line strategies for RA treatment. This class of drugs target inflammatory reactions [177]. An alternative classification system distinguishes conventional synthetic chemical compounds (csDMARDs) and targeted synthetic DMARD (tsDMARDs) [183]. Despite the effects of DMARDs on the phlogistic environment, they display several contraindications and side effects, as they interfere with the immune system by enhancing the susceptibility to infections [175]. Accordingly, research efforts generated a new class of drug, biological DMARDs (bDMARDs) treatments, which envisage the use of biological agents [184,185]. (Figure 6). Methotrexate (MTX), firstly used for RA treatment, inhibits the proliferation of inflammatory synovial cells and reduce macrophage and lymphocyte recruitment functions [175]. JAK inhibitors are a class of tsDMARDs, which block the JAK/STAT signalling pathway involved in the signalling transduction of several cytokines [186]. This pathway, composed of JAK1, JAK2, JAK3, and the tyrosine kinase 2 (TyK2), mediates intracellular signals through the transcription factor, STAT [187]. Tofacitinib and baricitinib are two JAK inhibitors approved by the Food and Drug Administration/European Medicines Agency (FDA/EMA) for RA treatment, which impair T lymphocyte RANKL production but not OCs differentiation and function [188] and promote bone formation and repair [189]. Autophagy regulates the innate and adaptative immune system and plays a crucial role in osteoclastogenesis [180]. In an arthritis model, the inhibition of autophagy contributed to reducing bone erosion and OCs number; suggesting its potential role in bone degradation [190]. In this light, drugs lowering autophagy might be another alternative to prevent bone resorption. bDMARDs can be divided into different subfamilies depending on their biological targets. They can include monoclonal antibodies ( $\mathrm{mAbs}$ ) and modified proteins targeting either cytokines or cell-surface molecules [191]. Inhibiting inflammatory cytokine with an osteoclastogenic profile can be a valid approach for blocking OCs-mediated bone resorption; thus, preventing focal bone loss. TNF inhibitors were among the first bDMARDs. Over the last years, scientists developed five main TNF- $\alpha$ inhibitors [192]. Tocilizumab is a humanised monoclonal antibody specific to IL-6R used as monotherapy or with MTX [161]. bDMARDs can also target cell surface molecules. In this light, modulating RANKL/OPG ratio at the pannus-bone interface can prevent bone erosions. Denosumab is a human monoclonal IgG2 antibody against RANKL, which suppress osteoclastogenesis by lowering bone resorption but with no effects on inflammation and cartilage erosion [176]. Targeting cell sources producing inflammatory mediators rather than their final products could be an alternative option due to the growing knowledge of molecules and signalling pathways associated with M1 and M2 [193-196]. 


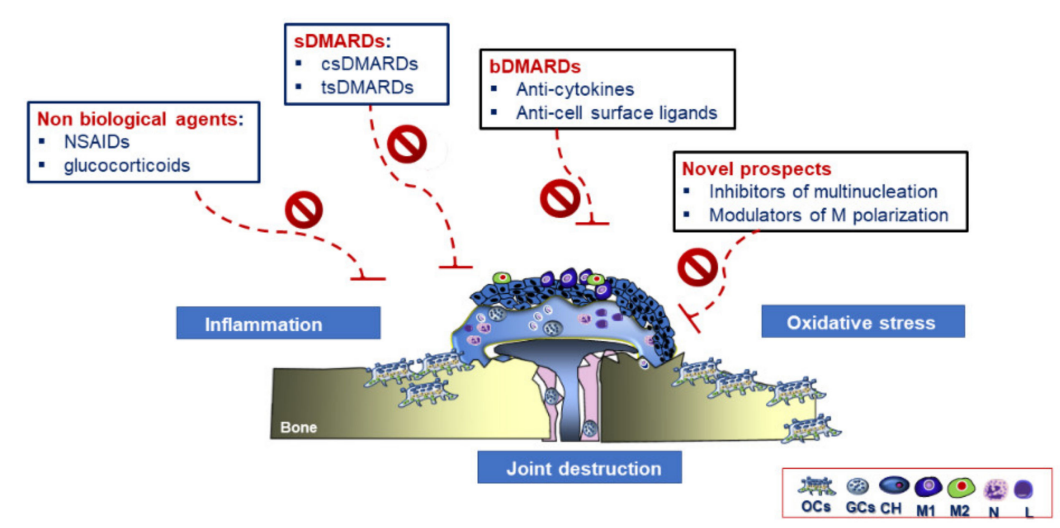

Figure 6. Graphical representation of standard treatments and new prospects for RA. Non-biological agents, synthetic disease-modifying anti-rheumatic drugs (sDMARDs), and biological disease-modifying anti-rheumatic drugs (bDMARDs) are among the main standard treatments for RA patients. Using inhibitors of multinucleation and modulators of macrophages $(\mathrm{M})$ polarisation could offer alternative novel strategies in RA.

Future Therapeutic Perspectives in RA Treatment

Despite remarkable progress in treatment modalities, there is still an essential demand for establishing new therapeutic targets. Being a multi-coloured disorder, a broad spectrum of alternative options, focused on inflammation, M-FM and osteoclastogenesis could be considered to prevent RA evolution.

First, targeting the inflammatory circuit, mainly supplied by activated macrophages, could envisage several alternatives: (i) neutralising major inflammatory cytokines via the use of inhibitors; and (ii) modulating the activation status of macrophages. Accordingly, clinical trials on TNF blockers [197], IL-1 [198], and IL-6 receptor blockage [199,200] gave evidence of the impact of inflammation on osteoclastogenesis by retarding or inhibiting bone erosion in RA patients. On the other hand, the use of selective agents switching the M1 towards M2 phenotype could improve RA mitigating the severe, continuous and debilitating pains symptoms. In this light, natural compounds, like triterpenoids, stilbenes, flavonoids, several miRNA and gene editing approaches could contribute to modulating macrophage phenotype $[167,185,201,202]$. IRAK-4 might be another therapeutic target to modulate M1/M2 polarisation by antagonising inflammatory osteolysis. Despite their promising results, further preclinical and clinical studies are necessary to define better what natural products and miRNAs are more relevant and elucidate what their signalling pathways are.

Second, targeting macrophage fusion and multinucleation could be a strategic alternative to avoid an excessive formation of OCs and GCs and enhanced inflammatory reactions, implicated in bone erosion and joint destruction. The technological advances could help to unravel conventional fusion mediators during the early stages by exploiting their pre-fusion transcription profile to develop new therapeutic strategies [7]. Inhibitors of multinucleation, already listed for OP, could be shared for treating especially bone loss in RA. Moreover, targeting KNN4, implicated in macrophage multinucleation [6], could be a potential alternative to ensure prevention of both inflammation and bone loss simultaneously to prevent inflammation-related bone loss. Notably, regulating P2RX7 expression on GCs and OCs could open essential perspectives for blocking the inflammatory circuit $[203,204]$. To this end, some scientists demonstrated through in vitro studies that its inhibition can prevent M-CSF/RANKL stimulated fusion of human monocytes, thereby inhibiting OCs multinucleation, however, its mechanism of action is still unknown [205].

Identifying the specific fusogenic molecules generating OCs and GCs side by side and clarifying the subtypes of GCs residing in the joint tissues thanks to the technological advances would be instrumental for designing more targeted strategies $[7,167,206]$ (Table 4). 
Table 4. Perspectives for rheumatoid arthritis (RA) therapy: biological targets for inhibiting inflammation and monocyte/macrophage fusion and multinucleation (M-FM) in osteoclasts (OCs) and giant cells (GCs).

\begin{tabular}{|c|c|c|c|}
\hline Biological Targets & $\begin{array}{l}\text { Therapeutic } \\
\text { Molecules/Compounds }\end{array}$ & $\begin{array}{l}\text { Effects on M-FM and } \\
\text { Inflammation in RA }\end{array}$ & Refs \\
\hline Tetraspanins & $\begin{array}{l}\text { Anti-tetraspanins } \\
\text { antibodies }\end{array}$ & $\begin{array}{l}\text { Inhibit fusion rate, and the size of } \\
\text { CGs obtained from intermediate } \\
\text { monocyte subset. }\end{array}$ & [150] \\
\hline $\begin{array}{l}\text { Tumour necrosis } \\
\text { factor-alpha } \\
(\text { TNF- } \alpha)\end{array}$ & TNF blockers & $\begin{array}{l}\text { Prevent the loss of bone mineral } \\
\text { density in RA patients. } \\
\text { Reduce serum levels of } \\
\text { carboxy-terminal telopeptide of type } 1 \\
\text { collagen and RANKL in RA patients. } \\
\text { - Prevent spine and hipbone loss. }\end{array}$ & {$[192,197]$} \\
\hline $\begin{array}{l}\text { Interleukin-1 } \\
\quad(\text { IL-1) }\end{array}$ & IL-1 inhibitors & $\begin{array}{l}\text { Improve both glycaemic and } \\
\text { inflammatory parameters in patients } \\
\text { with RA and type II diabetes. }\end{array}$ & [198] \\
\hline $\begin{array}{l}\text { Interleukin-6 receptor } \\
\quad(\mathbf{I L}-6 \mathbf{R})\end{array}$ & IL-6R blockers & $\begin{array}{l}\text { - Are effective treatments in phase III } \\
\text { clinical trials in RA patients. }\end{array}$ & {$[199,200]$} \\
\hline JAK/STAT cascade & $\begin{array}{c}\text { JAK inhibitors } \\
\text { (JAK1, JAK2, JAK3) }\end{array}$ & $\begin{array}{l}\text { Inhibit transduction signal from type I } \\
\text { and II cytokine receptors. } \\
\text { Reduce } \\
\text { inflammatory-mediated effects. } \\
\text { Tofacitinib and baricitinib are two } \\
\text { JAK inhibitors approved by } \\
\text { FDA/EMA for RA patients. }\end{array}$ & [187-189] \\
\hline P2X7 signalling & Anti-P2X7 antibody & $\begin{array}{l}\text { - Prevents M-CSF/RANKL stimulated } \\
\text { fusion of human monocytes. }\end{array}$ & [205] \\
\hline Mir127 & Antagonist of mir127 & $\begin{array}{l}\text { Modulates macrophage polarization } \\
\text { in favour of M2 macrophage subset. } \\
\text { Reduces the expression of } \\
\text { osteoclastogenic cytokines. }\end{array}$ & {$[167,202]$} \\
\hline $\begin{array}{l}\text { Macrophage } \\
\text { polarization }\end{array}$ & $\begin{array}{l}\text { Nutraceuticals } \\
\text { (tripertenoids, } \\
\text { stilbenes, flavonoids) }\end{array}$ & $\begin{array}{l}\text { Promote macrophage polarization } \\
\text { toward wound-healing M2 } \\
\text { activation status. } \\
\text { घrevent inflammatory osteolysis. }\end{array}$ & [185] \\
\hline Dysbiosis & $\begin{array}{l}\text { Disease-modifying } \\
\text { anti-rheumatic drugs } \\
\text { (DMARDs) }\end{array}$ & $\begin{array}{l}\text { Target cytokines, nonspecific immune } \\
\text { suppression or T-cell and } \\
\text { B-cell activation. } \\
\text { - Interfere in various pro-inflammatory } \\
\text { signalling pathways. } \\
\text { - Promote partial restoration of eubiotic } \\
\text { gut microbiota. }\end{array}$ & {$[207,208]$} \\
\hline
\end{tabular}

Third, getting a better understanding of the influence of anti-rheumatic drugs on microbiota and their subsequent effects on the immune system might be instrumental for selecting drugs with limited side effects on immune cells. Combining standard treatments with probiotics or natural compounds might be an alternative for inhibiting typical catabolic and inflammatory processes by preserving the composition and function of the microbiota in RA patients, which often display dysbiosis $[207,208]$.

The knowledge from studies addressing these aspects will be instrumental for improving current therapeutic options and redesigning more targeted approaches in the future depending on the stage of disease severity.

\section{Conclusions}

OP and RA are worldwide concerns, sharing some clinical and biological features of bone loss because of the alteration of the bone remodelling process, with an enormous burden for the health 
care system. Therefore, identifying and developing effective and therapeutic options is paramount to diseases treatments. Controlling aberrant inflammatory signals while preserving bone homeostasis is a significant challenge for both OP and RA. Interestingly, the macrophage multinucleation could be a biological target being a phenomenon perturbed in bone and inflammatory disorders, thereby opening valuable therapeutic insights in both RA and OP. In this light, targeting specific fusogenic determinants, like DC-STAMP, Siglec-15, KNN4, P2XR7, implicated in either OCs or GCs formation could provide alternative strategies to inhibit the inflammatory and degenerative processes in RA and $\mathrm{OP}$, which culminate in joint destruction. Targeting a particular cell macrophage subset could be a valid strategy to regulate their balance in these disorders, because of the influence of M1 and M2 macrophages on OCs and GCs formation. This review provides an up-to-date overview of M-FM in generating OCs and GCs in both disorders and the ongoing researches on the role of inflammation in driving the heterogeneous and dynamic macrophage phenotype and the formation of mature multinucleated. However, further in-depth studies focused on the mechanism and timing of M-FM, the fusion machinery in OCs and GCs biology are necessary for better elucidating their role in OP and RA.

Author Contributions: Conceptualisation, L.G.; G.D.; methodology, L.G; G.D; software, L.G.; G.D.; validation, L.G.; F.G.; G.D.; formal analysis, L.G.; G.D.; B.G.; investigation, L.G.; F.G.; L.R.; B.G.; G.D.; writing-original draft preparation, L.G. and G.D.; writing-review and editing, L.G.; F.G.; L.R.; B.G.; G.D.; visualisation, L.G.; F.G.; L.R.; B.G.; G.D.; supervision, L.G., F.G., L.R.; B.G., G.D. All authors have read and agreed to the published version of the manuscript.

Funding: This research was funded by the Italian Ministry of Health, 5× 1000 Funds anno 2016. "Malattie osteoarticolari: fisiopatologia e strategie terapeutiche innovative".

Acknowledgments: The authors wish to thank Patrizia Rappini for technical help.

Conflicts of Interest: The authors declare no conflict of interest.

\section{References}

1. Fu, S.Q.; Wang, Z.Y.; Jiang, Z.M.; Bi, Z.M.; Liu, E.H. Integration of zebrafish model and network pharmacology to explore possible action mechanisms of morinda officinalis for treating osteoporosis. Chem. Biodivers. 2020. [CrossRef]

2. Bombak, A.E.; Hanson, H.M. Qualitative insights from the osteoporosis research: A narrative review of the literature. J. Osteoporos 2016, 7915041. [CrossRef]

3. Goldring, S.R.; Gravallese, E.M. Mechanisms of bone loss in inflammatory arthritis: Diagnosis and therapeutic implications. Arthritis Res. 2000, 2, 33-37. [CrossRef]

4. Walsh, N.C.; Reinwald, S.; Manning, C.A.; Condon, K.W.; Iwata, K.; Burr, D.B.; Gravallese, E.M. Osteoblast function is compromised at sites of focal bone erosion in inflammatory arthritis. J. Bone Miner. Res. 2009, 24, 1572-1585. [CrossRef]

5. Karmakar, S.; Kay, J.; Gravallese, E.M. Bone damage in rheumatoid arthritis: Mechanistic insights and approaches to prevention. Rheum. Dis. Clin. N. Am. 2010, 36, 385-404. [CrossRef]

6. Kang, H.; Kerloc, A.; Rotival, M.; Xu, X.; Zhang, Q.; Souza, Z.D.; Kim, M.; Scholz, J.C.; Ko, J.; Srivastava, P.K.; et al. Kcnn4 is a regulator of macrophage multinucleation in bone homeostasis and inflammatory disease. Cell Rep. 2014, 8, 1210-1224. [CrossRef]

7. Pereira, M.; Petretto, E.; Gordon, S.; Bassett, J.H.D.; Williams, G.R.; Behmoaras, J. Common signalling pathways in macrophage and osteoclast multinucleation. J. Cell Sci. 2018, 131. [CrossRef]

8. Brodbeck, W.G.; Anderson, J.M. Giant cell formation and function. Curr. Opin. Hematol. 2009, 16, 53-57. [CrossRef] [PubMed]

9. Humphrey, M.B.; Daws, M.R.; Spusta, S.C.; Niemi, E.C.; Torchia, J.A.; Lanier, L.L.; Seaman, W.E.; Nakamura, M.C. TREM2, a DAP12-associated receptor, regulates osteoclast differentiation and function. J. Bone Miner. Res. 2006, 21, 237-245. [CrossRef] [PubMed]

10. Helming, L.; Gordon, S. Molecular mediators of macrophage fusion. Trends Cell Biol. 2009, 19, 514-522. [CrossRef] [PubMed]

11. Soysa, N.S.; Alles, N. Positive and negative regulators of osteoclast apoptosis. Bone Rep. 2019, 11, 100225. [CrossRef] [PubMed] 
12. Enelow, R.I.; Sullivan, G.W.; Carper, H.T.; Mandell, G.L. Cytokine-induced human multinucleated giant cells have enhanced candidacidal activity and oxidative capacity compared with macrophages. J. Infect. Dis. 1992, 166, 664-668. [CrossRef] [PubMed]

13. Matsuyama, T.; Nakashima, N.; Matsuda, T.; Nakamura, H.; Uchida, S.; Abe, T. Induction of multinucleated giant cells from rheumatoid arthritis (RA) synovial adherent cells by anti-DR antibody. Clin. Exp. Immunol. 1994, 98, 257-263. [CrossRef] [PubMed]

14. Quinn, M.T.; Schepetkin, I.A. Role of NADPH oxidase in formation and function of multinucleated giant cells. J. Innate Immun. 2009, 1, 509-526. [CrossRef] [PubMed]

15. Prieto-Potin, I.; Largo, R.; Roman-Blas, J.A.; Herrero-Beaumont, G.; Walsh, D.A. Characterization of multinucleated giant cells in synovium and subchondral bone in knee osteoarthritis and rheumatoid arthritis. BMC Musculoskelet. Disord. 2015, 16, 1-10. [CrossRef] [PubMed]

16. Lampiasi, N.; Russo, R.; Zito, F. The alternative faces of macrophage generate osteoclasts. Biomed Res. Int. 2016, 2016. [CrossRef] [PubMed]

17. Youn, M.-Y.; Takada, I.; Imai, Y.; Yasuda, H.; Kato, S. Transcriptionally active nuclei are selective in mature multinucleated osteoclasts. Genes Cells 2010, 15, 1025-1035. [CrossRef] [PubMed]

18. Ying, P.; Ribet, A.M.B.; Pavlos, N.J. Membrane trafficking in osteoclasts and implications for osteoporosis. Biochem. Soc. Trans. 2019, 47, 639-650.

19. Takito, J.; Inoue, S.; Nakamura, M. The sealing zone in osteoclasts: A self-organized structure on the bone. Int. J. Mol. Sci. 2018, 19, 984. [CrossRef] [PubMed]

20. Stenbeck, G. Formation and function of the ruffled border in osteoclasts. Semin. Cell Dev. Biol. 2002, 13, $285-292$. [CrossRef]

21. Itzstein, C.; Coxon, F.P.; Rogers, M.J. The regulation of osteoclast function and bone resorption by small GTPases. Small GTPases 2011, 2, 117-130. [CrossRef] [PubMed]

22. Takito, J.; Otsuka, H.; Yanagisawa, N.; Arai, H.; Shiga, M.; Inoue, M.; Nonaka, N.; Nakamura, M. Regulation of osteoclast multinucleation by the actin cytoskeleton signaling network. J. Cell. Physiol. 2015, 230, 395-405. [CrossRef] [PubMed]

23. Tiedemann, K.; Le Nihouannen, D.; Fong, J.E.; Hussein, O.; Barralet, J.E.; Komarova, S.V. Regulation of osteoclast growth and fusion by mTOR/raptor and mTOR/rictor/Akt. Front. Cell Dev. Biol. 2017, 5. [CrossRef] [PubMed]

24. Oikawa, T.; Oyama, M.; Kozuka-Hata, H.; Uehara, S.; Udagawa, N.; Saya, H.; Matsuo, K. Tks5-dependent formation of circumferential podosomes/invadopodia mediates cell-cell fusion. J. Cell Biol. 2012, 197, 553-568. [CrossRef]

25. Takito, J.; Nakamura, M.; Yoda, M.; Tohmonda, T.; Uchikawa, S.; Horiuchi, K.; Toyama, Y.; Chiba, K. The transient appearance of zipper-like actin superstructures during the fusion of osteoclasts. J. Cell Sci. 2012, 125, 662-672. [CrossRef] [PubMed]

26. Takahashi, A.; Kukita, A.; Li, Y.J.; Zhang, J.Q.; Nomiyama, H.; Yamaza, T.; Ayukawa, Y.; Koyano, K.; Kukita, T. Tunneling nanotube formation is essential for the regulation of osteoclastogenesis. J. Cell. Biochem. 2013, 114, 1238-1247. [CrossRef]

27. Takito, J.; Nakamura, M. Precursors linked via the zipper-like structure or the filopodium during the secondary fusion of osteoclasts. Commun. Integr. Biol. 2012, 5, 453-457. [CrossRef] [PubMed]

28. Lemma, S.; Sboarina, M.; Porporato, P.E.; Zini, N.; Sonveaux, P.; Di Pompo, G.; Baldini, N.; Avnet, S. Energy metabolism in osteoclast formation and activity. Int. J. Biochem. Cell Biol. 2016, 79, 168-180. [CrossRef] [PubMed]

29. Golan, K.; Kollet, O.; Lapidot, T. Dynamic cross talk between S1P and CXCL12 regulates hematopoietic stem cells migration, development and bone remodeling. Pharmaceuticals 2013, 6, 1145-1169. [CrossRef] [PubMed]

30. Aubin, J.E.; Bonnelye, E. Osteoprotegerin and its ligand: A new paradigm for regulation of osteoclastogenesis and bone resorption. Osteoporos. Int. 2000, 11, 905-913. [CrossRef]

31. Wada, T.; Nakashima, T.; Hiroshi, N.; Penninger, J.M. RANKL-RANK signaling in osteoclastogenesis and bone disease. Trends Mol. Med. 2006, 12, 17-25. [CrossRef] [PubMed]

32. Grössinger, E.M.; Kang, M.; Bouchareychas, L.; Sarin, R.; Haudenschild, D.R.; Borodinsky, L.N.; Adamopoulos, I.E. $\mathrm{Ca}^{2+}$-dependent regulation of NFATc1 via KCa3.1 in inflammatory osteoclastogenesis. J. Immunol. 2018, 200, 749-757. [CrossRef] 
33. Nishikawa, K.; Nakashima, T.; Hayashi, M.; Fukunaga, T.; Kato, S.; Kodama, T.; Takahashi, S.; Calame, K.; Takayanagi, H. Blimp1-mediated repression of negative regulators is required for osteoclast differentiation. Proc. Natl. Acad. Sci. USA 2010, 107, 3117-3122. [CrossRef]

34. Sun, X.; Zhang, C.; Guo, H.; Chen, J.; Tao, Y.; Wang, F.; Lin, X.; Liu, Q.; Su, L.; Qin, A. Pregnenolone inhibits osteoclast differentiation and protects against lipopolysaccharide-induced inflammatory bone destruction and ovariectomy-induced bone loss. Front. Pharmacol. 2020, 11, 1-15. [CrossRef]

35. Xiao, J.; Xiang, C.; Xijie, Y. MicroRNAs in osteoclastogenesis and function: Potential therapeutic targets for osteoporosis. Int. J. Mol. Sci. 2016, 17, 349. [CrossRef]

36. Li, K.; Chen, S.; Cai, P.; Chen, K.; Li, L.; Yang, X.; Yi, J.; Luo, X.; Du, Y.; Zheng, H. MiRNA-483-5p is involved in the pathogenesis of osteoporosis by promoting osteoclast differentiation. Mol. Cell. Probes 2020, 49. [CrossRef]

37. Dou, C.; Zhang, C.; Kang, F.; Yang, X.; Jiang, H.; Bai, Y.; Xiang, J.; Xu, J.; Dong, S. MiR-7b directly targets DC-STAMP causing suppression of NFATc1 and c-Fos signaling during osteoclast fusion and differentiation. Biochim. Biophys. Acta Gene Regul. Mech. 2014, 1839, 1084-1096. [CrossRef]

38. Lee, N.K.; Choi, Y.G.; Baik, J.Y.; Han, S.Y.; Jeong, D.W.; Bae, Y.S.; Kim, N.; Lee, S.Y. A crucial role for reactive oxygen species in RANKL-induced osteoclast differentiation. Blood 2005, 106. [CrossRef]

39. Irie, N.; Takada, Y.; Watanabe, Y.; Matsuzaki, Y.; Naruse, C.; Asano, M.; Iwakura, Y.; Suda, T.; Matsuo, K. Bidirectional signaling through EphrinA2-EphA2 enhances osteoclastogenesis and suppresses osteoblastogenesis. J. Biol. Chem. 2009, 284, 14637-14644. [CrossRef]

40. Costa, A.G.; Cusano, N.E.; Silva, B.C.; Cremers, S.; Bilezikian, J.P. Cathepsin K: Its skeletal actions and role as a therapeutic target in osteoporosis. Nat. Rev. Rheumatol. 2011, 7, 447-456. [CrossRef]

41. Chiu, W.S.M.; McManus, J.F.; Notini, A.J.; Cassady, A.I.; Zajac, J.D.; Davey, R.A. Transgenic mice that express Cre recombinase in osteoclasts. Genesis 2004, 39, 178-185. [CrossRef]

42. Takito, J.; Otsuka, H.; Inoue, S.; Kawashima, T.; Nakamura, M. Symmetrical retrograde actin flow in the actin fusion structure is involved in osteoclast fusion. Biol. Open 2017, 6, 1104-1114. [CrossRef]

43. Søe, K.; Hobolt-Pedersen, A.S.; Delaisse, J.M. The elementary fusion modalities of osteoclasts. Bone 2015, 73, 181-189. [CrossRef]

44. Ishii, T.; Ruiz-Torruella, M.; Ikeda, A.; Shindo, S.; Movila, A.; Mawardi, H.; Albassam, A.; Kayal, R.A.; Al-Dharrab, A.A.; Egashira, K.; et al. OC-STAMP promotes osteoclast fusion for pathogenic bone resorption in periodontitis via up-regulation of permissive fusogen CD9. FASEB J. 2018, 32, 4016-4030. [CrossRef]

45. Samanna, V.; Ma, T.; Mak, T.W.; Rogers, M.; Chellaiah, M.A. Actin polymerization modulates CD44 surface expression, MMP-9 activation, and osteoclast function. J. Cell. Physiol. 2007, 213, 710-720. [CrossRef]

46. Sodek, J.; Zhu, B.; Huynh, M.-H.; Brown, T.J.; Ringuette, M. Novel functions of the matricellular proteins Osteopontin and Osteonectin/SPARC. Connect. Tissue Res. 2002, 43, 308-319. [CrossRef]

47. Georgess, D.; Machuca-Gayet, I.; Blangy, A.; Jurdic, P. Podosome organization drives osteoclast-mediated bone resorption. Cell Adhes. Migr. 2014, 8, 192-204. [CrossRef]

48. Chellaiah, M.A.; Ma, T. Membrane localization of membrane type 1 matrix metalloproteinase by CD44 regulates the activation of pro-matrix Metalloproteinase 9 in Osteoclasts. Biomed Res. Int. 2013, $2013,13$. [CrossRef]

49. Khan, U.A.; Hashimi, S.M.; Bakr, M.M.; Forwood, M.R.; Morrison, N.A. CCL2 and CCR2 are essential for the formation of Osteoclasts and foreign body giant cells. J. Cell. Biochem. 2016, 117, 382-389. [CrossRef]

50. Miyamoto, K.; Ninomiya, K.; Sonoda, K.H.; Miyauchi, Y.; Hoshi, H.; Iwasaki, R.; Miyamoto, H.; Yoshida, S.; Sato, Y.; Morioka, H.; et al. MCP-1 expressed by osteoclasts stimulates osteoclastogenesis in an autocrine/paracrine manner. Biochem. Biophys. Res. Commun. 2009, 383, 373-377. [CrossRef]

51. Ishii, M.; Iwai, K.; Koike, M.; Ohshima, S.; Kudo-Tanaka, E.; Ishii, T.; Mima, T.; Katada, Y.; Miyatake, K.; Uchiyama, Y.; et al. RANKL-induced expression of tetraspanin CD9 in lipid raft membrane microdomain is essential for cell fusion during osteoclastogenesis. J. Bone Miner. Res. 2006, 21, 965-976. [CrossRef]

52. Kim, K.; Lee, S.H.; Jung, H.K.; Choi, Y.; Kim, N. NFATc1 induces osteoclast fusion via up-regulation of Atp6v0d2 and the Dendritic Cell-Specific Transmembrane Protein (DC-STAMP). Mol. Endocrinol. 2008, 22, 176-185. [CrossRef]

53. Mensah, K.A.; Ritchlin, C.T.; Schwarz, E.M. RANKL induces heterogeneous DC-STAMPlo and DC-STAMPhi osteoclast precursors of which the DC-STAMPlo precursors are the master fusogens. J. Cell. Physiol. 2010, 223, 76-83. [CrossRef] 
54. Chiu, Y.H.; Mensah, K.A.; Schwarz, E.M.; Ju, Y.; Takahata, M.; Feng, C.; McMahon, L.A.; Hicks, D.G.; Panepento, B.; Keng, P.C.; et al. Regulation of human osteoclast development by dendritic cell-specific transmembrane protein (DC-STAMP). J. Bone Miner. Res. 2012, 27, 79-92. [CrossRef]

55. Hobolt-Pedersen, A.S.; Delaissé, J.M.; Søe, K. Osteoclast fusion is based on heterogeneity between fusion partners. Calcif. Tissue Int. 2014, 95, 73-82. [CrossRef]

56. Yi, T.G.; Kim, H.J.; Cho, J.Y.; Woo, K.M.; Ryoo, H.M.; Kim, G.S.; Baek, J.H. Tetraspanin CD9 regulates osteoclastogenesis via regulation of p44/42 MAPK activity. Biochem. Biophys. Res. Commun. 2006, 347, 178-184. [CrossRef]

57. Witwicka, H.; Hwang, S.Y.; Reyes-Gutierrez, P.; Jia, H.; Odgren, P.E.; Donahue, L.R.; Birnbaum, M.J.; Odgren, P.R. Studies of OC-STAMP in osteoclast fusion: A new knockout mouse model, rescue of cell fusion, and transmembrane topology. PLoS ONE 2015, 10, e0128275. [CrossRef]

58. Møller, A.M.J.; Delaissé, J.M.; Søe, K. Osteoclast fusion: Time-lapse reveals involvement of CD47 and Syncytin-1 at different stages of nuclearity. J. Cell. Physiol. 2017, 232, 1396-1403. [CrossRef]

59. Kameda, Y.; Takahata, M.; Mikuni, S.; Shimizu, T.; Hamano, H.; Angata, T.; Hatakeyama, S.; Kinjo, M.; Iwasaki, N. Siglec-15 is a potential therapeutic target for postmenopausal osteoporosis. Bone 2015, 71, 217-226. [CrossRef]

60. Hiruma, Y.; Hirai, T.; Tsuda, E. Siglec-15, a member of the sialic acid-binding lectin, is a novel regulator for osteoclast differentiation. Biochem. Biophys. Res. Commun. 2011, 409, 424-429. [CrossRef]

61. Ishida-Kitagawa, N.; Tanaka, K.; Bao, X.; Kimura, T.; Miura, T.; Kitaoka, Y.; Hayashi, K.; Sato, M.; Maruoka, M.; Ogawa, T.; et al. Siglec-15 protein regulates formation of functional osteoclasts in concert with DNAX-activating protein of $12 \mathrm{kDa}$ (DAP12). J. Biol. Chem. 2012, 287, 17493-17502. [CrossRef]

62. Hiruma, Y.; Tsuda, E.; Maeda, N.; Okada, A.; Kabasawa, N.; Miyamoto, M.; Hattori, H.; Fukuda, C. Impaired osteoclast differentiation and function and mild osteopetrosis development in Siglec-15-deficient mice. Bone 2013, 53, 87-93. [CrossRef]

63. Stuible, M.; Moraitis, A.; Fortin, A.; Saragosa, S.; Kalbakji, A.; Filion, M.; Tremblay, G.B. Mechanism and function of monoclonal antibodies targeting Siglec-15 for therapeutic inhibition of osteoclastic bone resorption. J. Biol. Chem. 2014, 289, 6498-6512. [CrossRef]

64. Shimada-Sugawara, M.; Sakai, E.; Okamoto, K.; Fukuda, M.; Izumi, T.; Yoshida, N.; Tsukuba, T. Rab27A regulates transport of cell surface receptors modulating multinucleation and lysosome-related Organelles in Osteoclasts. Sci. Rep. 2015, 5, 1-11. [CrossRef]

65. Pata, M.; Vacher, J. Ostm1 bifunctional roles in Osteoclast maturation : Insights from a mouse model mimicking a human OSTM1 mutation. J. Bone Miner. Res. 2018, 33, 888-898. [CrossRef]

66. Kim, K.; Kim, J.H.; Kim, I.; Lee, J.; Seong, S.; Park, Y.W.; Kim, N. MicroRNA-26a regulates RANKL-induced osteoclast formation. Mol. Cells 2014, 38, 75-80. [CrossRef]

67. Tang, L.; Yin, Y.; Liu, J.; Li, Z.; Lu, X. MIR-124 attenuates osteoclastogenic differentiation of bone marrow monocytes via targeting Rab27a. Cell. Physiol. Biochem. 2017, 43, 1663-1672. [CrossRef]

68. Nishida, H.; Suzuki, H.; Madokoro, H.; Hayashi, M.; Morimoto, C.; Sakamoto, M.; Yamada, T. Blockade of CD26 signaling inhibits human osteoclast development. J. Bone Miner. Res. 2014, 29, 2439-2455. [CrossRef]

69. Maile, L.A.; Demambro, V.E.; Wai, C.; Aday, A.W.; Capps, B.E.; Beamer, W.G.; Rosen, C.J.; Clemmons, D.R. An essential role for the association of CD47 to SHPS-1 in skeletal remodeling. J. Bone Miner. Res. 2011, 26, 2068-2081. [CrossRef]

70. Kanemoto, S.; Kobayashi, Y.; Yamashita, T.; Miyamoto, T.; Cui, M.; Asada, R.; Cui, X.; Hino, K.; Kaneko, M.; Takai, T.; et al. Luman is involved in osteoclastogenesis through the regulation of DC-STAMP expression, stability and localization. J. Cell Sci. 2015, 128, 4353-4365. [CrossRef]

71. Lee, S.H.; Rho, J.; Jeong, D.; Sul, J.Y.; Kim, T.; Kim, N.; Kang, J.S.; Miyamoto, T.; Suda, T.; Lee, S.K.; et al. V-ATPase V0 subunit d2-deficient mice exhibit impaired osteoclast fusion and increased bone formation. Nat. Med. 2006, 12, 1403-1409. [CrossRef] [PubMed]

72. Helming, L.; Tomasello, E.; Kyriakides, T.R.; Martinez, F.O.; Takai, T.; Gordon, S.; Vivier, E. Essential role of DAP12 signaling in macrophage programming into a fusion-competent state. Sci. Signal. 2008, 1, ra11. [CrossRef] [PubMed]

73. Søe, K.; Andersen, T.L.; Hinge, M.; Rolighed, L.; Marcussen, N.; Delaisse, J.-M. Coordination of fusion and trafficking of pre-osteoclasts at the marrow-bone interface. Calcif. Tissue Int. 2019, 105, 430-445. [CrossRef] 
74. Sun, H.; Kaartinen, M.T. Assessment of expression and specific activities of transglutaminases TG1, TG2, and FXIII-A during osteoclastogenesis. Anal. Biochem. 2020, 591, 113512. [CrossRef]

75. Agrawal, A.; Buckley, K.A.; Bowers, K.; Furber, M.; Gallagher, J.A.; Gartland, A. The effects of P2X7 receptor antagonists on the formation and function of human osteoclasts in vitro. Purinergic Signal. 2010, 6, 307-315. [CrossRef] [PubMed]

76. Kim, H.; Walsh, M.C.; Yu, J.; Laskoski, P.; Takigawa, K.; Takegahara, N.; Choi, Y. Methylosome protein 50 associates with the purinergic receptor $\mathrm{P} 2 \mathrm{X} 5$ and is involved in osteoclast maturation. FEBS Lett. 2020, 594, 144-152. [CrossRef] [PubMed]

77. Kim, H.; Walsh, M.C.; Takegahara, N.; Middleton, S.A.; Kim, J.; Choi, Y. The purinergic receptor P2X5 regulates inflammasome activity and hyper-multinucleation of murine osteoclasts. Sci. Rep. 2017, 7, 1-11. [CrossRef]

78. Kajitani, N.; Yamada, T.; Kawakami, K.; Matsumoto, K. Ichi TNX deficiency results in bone loss due to an increase in multinucleated osteoclasts. Biochem. Biophys. Res. Commun. 2019, 512, 659-664. [CrossRef]

79. Shin, N.Y.; Choi, H.; Neff, L.; Wu, Y.; Saito, H.; Ferguson, S.M.; De Camilli, P.D.; Baron, R. Dynamin and endocytosis are required for the fusion of osteoclasts and myoblasts. J. Cell Biol. 2014, 207, 73-89. [CrossRef]

80. Notomi, T.; Ezura, Y.; Noda, M. Identification of two-pore channel 2 as a novel regulator of osteoclastogenesis. J. Biol. Chem. 2012, 287, 35057-35064. [CrossRef]

81. Shirakawa, J.; Takegahara, N.; Kim, H.; Lee, S.H.; Sato, K.; Yamagishi, S.; Choi, Y. Flrt2 is involved in fine-tuning of osteoclast multinucleation. BMB Rep. 2019, 52, 514-519. [CrossRef] [PubMed]

82. Zhou, Y.; Lewis, T.L.; Robinson, L.J.; Brundage, K.M.; Schafer, R.; Martin, K.H.; Blair, H.C.; Soboloff, J.; Barnett, J.B. The role of calcium release activated calcium channels in osteoclast differentiation. J. Cell. Physiol. 2011, 226, 1082-1089. [CrossRef] [PubMed]

83. Go, E.M.; Oh, J.H.; Park, J.H.; Lee, S.Y.; Lee, N.K. Spi-C positively regulates RANKL-mediated osteoclast differentiation and function. Exp. Mol. Med. 2020, 52, 691-701. [CrossRef]

84. Hoshino, A.; Iimura, T.; Ueha, S.; Hanada, S.; Maruoka, Y.; Mayahara, M.; Suzuki, K.; Imai, T.; Ito, M.; Manome, Y.; et al. Deficiency of chemokine receptor CCR1 causes osteopenia due to impaired functions of osteoclasts and osteoblasts. J. Biol. Chem. 2010, 285, 28826-28837. [CrossRef]

85. Nagai, Y.; Osawa, K.; Fukushima, H.; Tamura, Y.; Aoki, K.; Ohya, K.; Yasuda, H.; Hikiji, H.; Takahashi, M.; Seta, Y.; et al. P130Cas, Crk-associated substrate, plays important roles in osteoclastic bone resorption. J. Bone Miner. Res. 2013, 28, 2449-2462. [CrossRef]

86. Lizneva, D.; Yuen, T.; Sun, L.; Kim, S.M.; Atabiekov, I.; Munshi, L.B.; Epstein, S.; New, M.; Zaidi, M. Emerging concepts in the epidemiology, pathophysiology, and clinical care of osteoporosis across the menopausal transition. Matrix Biol. 2018, 71, 70-81. [CrossRef]

87. Cagnetta, V.; Patella, V. The role of the immune system in the physiopathology of osteoporosis. Clin. Cases Miner. Bone Metab. 2012, 9, 85-88. [PubMed]

88. Cummings, S.R.; Nevitt, M.C.; Browner, W.S.; Stone, K.; Fox, K.M.; Ensrud, K.E.; Cauley, J.; Black, D.; Vogt, T.M. Risk factors for hip fracture in white women. Study of osteoporotic fractures research group. N. Engl. J. Med. 1995, 332. [CrossRef] [PubMed]

89. Raisz, L.G. Pathogenesis of osteoporosis: Concepts, conflicts, and prospects. J. Clin. Investig. 2005, 115. [CrossRef]

90. Eriksen, E.F.; Hodgson, S.F.; Eastell, R.; Cedel, S.L.; O’ Fallon, W.M.; Riggs, B.L. Cancellous bone remodeling in type I (postmenopausal) osteoporosis: Quantitative assessment of rates of formation, resorption, and bone loss at tissue and cellular levels. J. Bone Miner. Res. 1990, 5. [CrossRef]

91. Lean, J.M.; Davis, J.T.; Fuller, K.; Jagger, C.J.; Kirstein, B.; Partington, G.A.; Urry, Z.L.; Chambers, T.J. A crucial role for thiol antioxidants in estrogen-deficiency bone loss. J. Clin. Investig. 2003, 112. [CrossRef]

92. De Martinis, M.; Sirufo, M.M.; Suppa, M. IL-33 / IL-31 axis in osteoporosis. Int. J. Mol. Sci. 2020, $21,1239$. [CrossRef]

93. Faienza, M.F.; Ventura, A.; Marzano, F.; Cavallo, L. Postmenopausal osteoporosis: The role of immune system cells. Clin. Dev. Immunol. 2013. [CrossRef] [PubMed]

94. Liao, Z.H.; Huang, T.; Xiao, J.W.; Gu, R.C.; Ouyang, J.; Wu, G.; Liao, H. Estrogen signaling effects on muscle-specific immune responses through controlling the recruitment and function of macrophages and $\mathrm{T}$ cells. Skelet. Muscle 2019, 9, 1-16. [CrossRef] [PubMed] 
95. Brunetti, G.; Storlino, G.; Oranger, A.; Colaianni, G.; Faienza, M.F.; Ingravallo, G.; Di Comite, M.; Reseland, J.E.; Celi, M.; Tarantino, U.; et al. LIGHT/TNFSF14 regulates estrogen deficiency-induced bone loss. J. Pathol. 2020, 250, 440-451. [CrossRef]

96. Pacifici, R. The inmune system and bone. Arch. Biochem. Biophys. 2010, 503, 41-53. [CrossRef] [PubMed]

97. Li, J.Y.; Chassaing, B.; Tyagi, A.M.; Vaccaro, C.; Luo, T.; Adams, J.; Darby, T.M.; Weitzmann, M.N.; Mulle, J.G.; Gewirtz, A.T.; et al. Sex steroid deficiency-associated bone loss is microbiota dependent and prevented by probiotics. J. Clin. Investig. 2016, 126, 2049-2063. [CrossRef] [PubMed]

98. Yang, D.H.; Yang, M.Y. The role of macrophage in the pathogenesis of osteoporosis. Int. J. Mol. Sci. 2019, 20, 2093. [CrossRef]

99. Dou, C.; Ding, N.; Zhao, C.; Hou, T.; Kang, F.; Cao, Z.; Liu, C.; Bai, Y.; Dai, Q.; Ma, Q.; et al. Estrogen deficiency-mediated M2 macrophage osteoclastogenesis contributes to M1/M2 ratio alteration in ovariectomized osteoporotic mice. J. Bone Miner. Res. 2018, 33, 899-908. [CrossRef]

100. Agidigbi, T.S.; Kim, C. Reactive oxygen species in osteoclast differentiation and possible pharmaceutical targets of ROS-mediated Osteoclast diseases. Int. J. Mol. Sci. 2019, 20, 3576. [CrossRef]

101. Manolagas, S.C. From estrogen-centric to aging and oxidative stress: A revised perspective of the pathogenesis of osteoporosis. Endocr. Rev. 2010, 31. [CrossRef] [PubMed]

102. Eghbali-Fatourechi, G.; Khosla, S.; Sanyal, A.; Boyle, W.J.; Lacey, D.L.; Riggs, B.L. Role of RANK ligand in mediating increased bone resorption in early postmenopausal women. J. Clin. Investig. 2003, 111. [CrossRef]

103. Wang, H.; Yang, G.; Xiao, Y.; Luo, G.; Li, G.; Li, Z. Friend or foe? Essential roles of osteoclast in maintaining skeletal health. Biomed. Res. Int. 2020, 2020. [CrossRef] [PubMed]

104. Kim, M.H.; Park, M.; Baek, S.H.; Kim, H.J.; Kim, S.H. Molecules and signaling pathways involved in the expression of OC-STAMP during osteoclastogenesis. Amino Acids 2011, 40, 1447-1459. [CrossRef]

105. Levine, J.P. Long-term estrogen and hormone replacement therapy for the prevention and treatment of osteoporosis. Curr. Womens Health Rep. 2003, 3, 181-186.

106. Levin, V.A.; Jiang, X.; Kagan, R. Estrogen therapy for osteoporosis in the modern era. Osteoporos. Int. 2018, 29, 1049-1055. [CrossRef]

107. Komm, B.S.; Chines, A.A. An update on selective estrogen receptor modulators for the prevention and treatment of osteoporosis. Maturitas 2012, 71, 221-226. [CrossRef]

108. Pinkerton, J.V.; Thomas, S. Use of SERMs for treatment in postmenopausal women. J. Steroid Biochem. Mol. Biol. 2014, 142, 142-154. [CrossRef]

109. Gałęzowska, J. Interactions between clinically used bisphosphonates and bone mineral: From coordination chemistry to biomedical applications and beyond. ChemMedChem 2018, 13, 289-302. [CrossRef]

110. Papapoulos, S.E. Bisphosphonates: How do they work? Best Pract. Res. Clin. Endocrinol. Metab. 2008, 22, 831-847. [CrossRef]

111. Coxon, F.P.; Thompson, K.; Roelofs, A.J.; Ebetino, F.H.; Rogers, M.J. Visualizing mineral binding and uptake of bisphosphonate by osteoclasts and non-resorbing cells. Bone 2008, 42, 848-860. [CrossRef] [PubMed]

112. Russell, R.G.G. Bisphosphonates: From bench to bedside. Ann. N. Y. Acad. Sci. 2006, 1068, 367-401. [CrossRef] [PubMed]

113. Lorentzon, M. Treating osteoporosis to prevent fractures: Current concepts and future developments. J. Intern. Med. 2019, 285, 381-394. [CrossRef] [PubMed]

114. Pazianas, M.; Van Der Geest, S.; Miller, P. Bisphosphonates and bone quality. Bonekey Rep. $2014,3,529$. [CrossRef] [PubMed]

115. Weivoda, M.M.; Chew, C.K.; Monroe, D.G.; Farr, J.N.; Atkinson, E.J.; Geske, J.R.; Eckhardt, B.; Thicke, B.; Ruan, M.; Tweed, A.J.; et al. Identification of osteoclast-osteoblast coupling factors in humans reveals links between bone and energy metabolism. Nat. Commun. 2020, 11. [CrossRef]

116. Ma, S.; Goh, E.L.; Jin, A.; Bhattacharya, R.; Boughton, O.R.; Patel, B.; Karunaratne, A.; Vo, N.T.; Atwood, R.; Cobb, J.P.; et al. Long-term effects of bisphosphonate therapy: Perforations, microcracks and mechanical properties. Sci. Rep. 2017, 7, 43399. [CrossRef]

117. Iwasaki, R.; Ninomiya, K.; Miyamoto, K.; Suzuki, T.; Sato, Y.; Kawana, H.; Nakagawa, T.; Suda, T.; Miyamoto, T. Cell fusion in osteoclasts plays a critical role in controlling bone mass and osteoblastic activity. Biochem. Biophys. Res. Commun. 2008, 377, 899-904. [CrossRef]

118. Ott, S.M. Long-term safety of bisphosphonates. J. Clin. Endocrinol. Metab. 2005, 90. [CrossRef] 
119. Hanley, D.A.; Adachi, J.D.; Bell, A.; Brown, V. Denosumab: Mechanism of action and clinical outcomes. Int. J. Clin. Pract. 2012, 66, 1139-1146. [CrossRef]

120. Zhou, Y.; Ma, X.; Wang, T.; Zhai, S. Comparative efficacy of bisphosphonates in short-term fracture prevention for primary osteoporosis: A systematic review with network meta-analyses. Osteoporos. Int. 2016, 27, 3289-3300. [CrossRef]

121. Beaudoin, C.; Jean, S.; Bessette, L.; Ste-Marie, L.-G.; Moore, L.; Brown, J.P. Denosumab compared to other treatments to prevent or treat osteoporosis in individuals at risk of fracture: A systematic review and meta-analysis. Osteoporos. Int. 2016, 27, 2835-2844. [CrossRef] [PubMed]

122. Bone, H.G.; Bolognese, M.A.; Yuen, C.K.; Kendler, D.L.; Miller, P.D.; Yang, Y.C.; Grazette, L.; Martin, J.S.; Gallagher, J.C. Effects of denosumab treatment and discontinuation on bone mineral density and bone turnover markers in postmenopausal women with low bone mass. J. Clin. Endocrinol. Metab. 2011, 96, 972-980. [CrossRef] [PubMed]

123. Haas, A.V.; LeBoff, M.S. Osteoanabolic agents for Osteoporosis. J. Endocr. Soc. 2018, 2, 922-932. [CrossRef] [PubMed]

124. Bandeira, L.; Lewiecki, E.M.; Bilezikian, J.P. Romosozumab for the treatment of osteoporosis. Expert Opin. Biol. Ther. 2017, 17, 255-263. [CrossRef] [PubMed]

125. Faienza, M.F.; Chiarito, M.; D’Amato, G.; Colaianni, G.; Colucci, S.; Grano, M.; Brunetti, G. Monoclonal antibodies for treating osteoporosis. Expert Opin. Biol. Ther. 2018, 18, 149-157. [CrossRef]

126. Watanabe, A.; Yoneyama, S.; Nakajima, M.; Sato, N.; Takao-Kawabata, R.; Isogai, Y.; Sakurai-Tanikawa, A.; Higuchi, K.; Shimo, A.; Yamatoya, H.; et al. Osteosarcoma in Sprague-Dawley rats after long-term treatment with teriparatide (human parathyroid hormone (1-34)). J. Toxicol. Sci. 2012, 37, 617-629. [CrossRef]

127. Anagnostis, P.; Gkekas, N.K.; Potoupnis, M.; Kenanidis, E.; Tsiridis, E.; Goulis, D.G. New therapeutic targets for osteoporosis. Maturitas 2019, 120,1-6. [CrossRef]

128. Luo, X.; Barbieri, D.; Zhang, Y.; Yang, Y.; Bruijn, J.D.; Yuan, H. Strontium ranelate in Osteoporosis. Curr. Pharm. Des. 2005, 8, 1907-1916. [CrossRef]

129. Kartner, N.; Manolson, M.F. Novel techniques in the development of osteoporosis drug therapy: The osteoclast ruffled-border vacuolar $\mathrm{H}^{+}$-ATPase as an emerging target. Expert Opin. Drug Discov. 2014, 9. [CrossRef]

130. Mukherjee, K.; Chattopadhyay, N. Pharmacological inhibition of cathepsin K: A promising novel approach for postmenopausal osteoporosis therapy. Biochem. Pharmacol. 2016, 117, 10-19. [CrossRef]

131. Dai, R.; Wu, Z.; Chu, H.Y.; Lu, J.; Lyu, A.; Liu, J.; Zhang, G. Cathepsin K: The action in and beyond bone. Front. Cell Dev. Biol. 2020, 8. [CrossRef] [PubMed]

132. An, J.; Hao, D.; Zhang, Q.; Chen, B.; Zhang, R.; Wang, Y.; Yang, H. Natural products for treatment of bone erosive diseases: The effects and mechanisms on inhibiting osteoclastogenesis and bone resorption. Int. Immunopharmacol. 2016, 36, 118-131. [CrossRef] [PubMed]

133. Rajput, R.; Wairkar, S.; Gaud, R. Nutraceuticals for better management of osteoporosis: An overview. J. Funct. Foods 2018, 47, 480-490. [CrossRef]

134. Dou, C.; Ding, N.; Luo, F.; Hou, T.; Cao, Z.; Bai, Y.; Liu, C.; Xu, J.; Dong, S. Graphene-based microRNA transfection blocks preosteoclast fusion to increase bone formation and vascularization. Adv. Sci. 2018, 5. [CrossRef] [PubMed]

135. Yin, Y.; Tang, L.; Chen, J.; Lu, X. MiR-30a attenuates osteoclastogenesis via targeting DC-STAMP-c-Fos-NFATc1 signaling. Am. J. Transl. Res. 2017, 9, 5743.

136. Wisitrasameewong, W.; Kajiya, M.; Movila, A.; Rittling, S.; Ishii, T.; Suzuki, M.; Matsuda, S.; Mazda, Y.; Torruella, M.R.; Azuma, M.M.; et al. DC-STAMP is an Osteoclast fusogen engaged in periodontal bone resorption. J. Dent. Res. 2017, 96, 685-693. [CrossRef]

137. Sato, D.; Takahata, M.; Ota, M.; Fukuda, C.; Hasegawa, T.; Yamamoto, T.; Amizuka, N.; Tsuda, E.; Okada, A.; Hiruma, Y.; et al. Siglec-15-targeting therapy protects against glucocorticoid-induced osteoporosis of growing skeleton in juvenile rats. Bone 2020, 135, 115331. [CrossRef]

138. Sato, D.; Takahata, M.; Ota, M.; Fukuda, C.; Tsuda, E.; Shimizu, T.; Okada, A.; Hiruma, Y.; Hamano, H.; Hiratsuka, S.; et al. Siglec-15-targeting therapy increases bone mass in rats without impairing skeletal growth. Bone 2018, 116, 172-180. [CrossRef]

139. Brooks, P.J.; Glogauer, M.; Mcculloch, C.A. An overview of the derivation and function of multinucleated giant cells and their role in pathologic processes. Am. J. Pathol. 2019, 189, 1145-1158. [CrossRef] 
140. Al-Maawi, S.; Orlowska, A.; Sader, R.; James Kirkpatrick, C.; Ghanaati, S. In Vivo cellular reactions to different biomaterials-Physiological and pathological aspects and their consequences. Semin. Immunol. 2017, 29, 49-61. [CrossRef]

141. Firestein, G.; McIness, I. Immunopathogenesis of rheumatoid arthritis. Immunity 2017, 46, 183-196. [CrossRef] [PubMed]

142. Moritag, I.; Okin, T.; Uekill, T.; Sakaguchi, K.; Enornoto, S.; Murota, S.; Medical, T. Expression on outer membranes of mannose residues, which are involved in osteoclast formation via cellular fusion events. J. Biol. Chem. 1994, 169, 17572-17576.

143. Katsuyama, E.; Miyamoto, H.; Kobayashi, T.; Sato, Y.; Hao, W.; Kanagawa, H.; Fujie, A.; Tando, T.; Watanabe, R.; Morita, M.; et al. Interleukin-1 receptor-associated Kinase-4 (IRAK4) promotes inflammatory osteolysis by activating Osteoclasts and inhibiting formation of foreign body giant cells. J. Biol. Chem. 2015, 290, 716-726. [CrossRef] [PubMed]

144. Vignery, A. Osteoclasts and giant cells: Macrophage-macrophage fusion mechanism. Int. J. Exp. Pathol. 2000, 81, 291-304. [CrossRef]

145. Han, X.; Sterling, H.; Chen, Y.; Saginario, C.; Brown, E.J.; Frazier, W.A.; Lindberg, F.P.; Vignery, A. CD47, a ligand for the macrophage fusion receptor, participates in macrophage multinucleation. J. Biol. Chem. 2000, 275, 37984-37992. [CrossRef]

146. Yagi, M.; Ninomiya, K.; Fujita, N.; Suzuki, T.; Iwasaki, R.; Morita, K.; Hosogane, N.; Matsuo, K.; Toyama, Y.; Suda, T.; et al. Induction of DC-STAMP by alternative activation and downstream signaling mechanisms. J. Bone Miner. Res. 2007, 22, 992-1001. [CrossRef]

147. Moreno, J.L.; Mikhailenko, I.; Tondravi, M.M.; Keegan, A.D. IL-4 promotes the formation of multinucleated giant cells from macrophage precursors by a STAT6-dependent, homotypic mechanism: Contribution of E-cadherin. J. Leukoc. Biol. 2007, 82, 1542-1553. [CrossRef]

148. Miyamoto, T. STATs and macrophage fusion. JAK STAT 2013, 2, e24777. [CrossRef]

149. Fiorino, C.; Harrison, R.E. E-cadherin is important for cell differentiation during osteoclastogenesis. Bone 2016, 86, 106-118. [CrossRef]

150. Champion, T.C.; Partridge, L.J.; Ong, S.M.; Malleret, B.; Wong, S.C.; Monk, P.N. Monocyte subsets have distinct patterns of tetraspanin expression and different capacities to form multinucleate giant cells. Front. Immunol. 2018, 9. [CrossRef]

151. Sissons, J.R.; Peschon, J.J.; Schmitz, F.; Gilchrist, M.; Aderem, A.; Sissons, J.R.; Peschon, J.J.; Schmitz, F.; Suen, R.; Gilchrist, M.; et al. Cutting edge: microRNA regulation of macrophage fusion into multinucleated giant cells. J Immunol 2012, 189, 22-27. [CrossRef] [PubMed]

152. Yang, X.; Chang, Y.; Wei, W. Emerging role of targeting macrophages in rheumatoid arthritis: Focus on polarization, metabolism and apoptosis. Cell Prolif. 2020, 1-12. [CrossRef]

153. Degboé, Y.; Rauwel, B.; Baron, M.; Boyer, J.; Ruyssen-witrand, A.; Constantin, A.; Davignon, J.; Lucas, R. Polarization of rheumatoid macrophages by TNF targeting through an IL-10 / STAT3 mechanism. Front. Immunol. 2019, 10, 1-14. [CrossRef] [PubMed]

154. Mills, C.D. Anatomy of a discovery: M1 and M2 macrophages. Front. Immunol. 2015, 6, 1-12. [CrossRef] [PubMed]

155. Ryszer, T. Understanding the mysterious M2 macrophage through activation markers and effector mechanisms. Mediat. Inflamm. 2020, 2015, 16-18. [CrossRef]

156. Oya, A.; Katsuyama, E.; Morita, M.; Sato, Y.; Kobayashi, T.; Miyamoto, K.; Nishiwaki, T.; Funayama, A.; Fujita, Y.; Kobayashi, T.; et al. Tumor necrosis factor receptor-associated factor 6 is required to inhibit foreign body giant cell formation and activate osteoclasts under inflammatory and infectious conditions. J. Bone Miner. Metab. 2018, 36, 679-690. [CrossRef]

157. Zhu, K.; Yang, C.; Dai, H.; Li, J.; Liu, W.; Luo, Y.; Zhang, X.; Wang, Q. Crocin inhibits titanium particle-induced inflammation and promotes osteogenesis by regulating macrophage polarization. Int. Immunopharmacol. 2019, 76, 105865. [CrossRef]

158. Amarasekara, D.S.; Yun, H.; Kim, S.; Lee, N.; Kim, H.; Rho, J. Regulation of osteoclast differentiation by cytokine networks. Immune Netw. 2018, 18, 1-18. [CrossRef]

159. Zhao, B. TNF and bone remodeling. Curr. Osteoporos. Rep. 2019, 15, 126-134. [CrossRef]

160. Adamopoulos, I.E.; Mellins, E.D. Alternative pathways of osteoclastogenesis in inflammatory arthritis. Nat. Rev. Rheumatol. 2015, 11, 189-194. [CrossRef] 
161. Walsh, N.C.; Gravallese, E.M. Bone remodeling in rheumatic disease: A question of balance. Immunol. Rev. 2010, 233, 301-312. [CrossRef] [PubMed]

162. Zhou, R.; Hu, W.; Ge, J. Functions of interleukin-34 and its emerging association with rheumatoid arthritis. Immunology 2016, 362-373. [CrossRef] [PubMed]

163. Cao, Y.; Jansen, I.D.C.; Sprangers, S.; Stap, J.; Leenen, P.J.M.; Everts, V.; Vries, T.J. De IL-1 b differently stimulates proliferation and multinucleation of distinct mouse bone marrow osteoclast precursor subsets. J. Leukoc. Biol. 2016, 100, 513-523. [CrossRef] [PubMed]

164. Falzoni, S.; Chiozzi, P.; Ferrari, D.; Buell, G.; Virgilio, F. Di P2X 7 receptor and polykarion formation. Mol. Biol. Cell 2000, 11, 3169-3176. [CrossRef] [PubMed]

165. Chiozzi, P.; Sanz, J.M.; Ferrari, D.; Falzoni, S.; Aleotti, A.; Buell, G.N.; Collo, G.; Di Virgilio, F. Spontaneous cell fusion in macrophage cultures expressing high levels of the P2Z/P2X7 receptor. J. Cell Biol. 1997, 138, 697-706. [CrossRef]

166. Savio, L.E.; de Andrade Mello, P.; da Silva, C.G.; Coutinho-Silva, R. The P2X7 receptor in inflammatory diseases: Angel or demon? Front. Pharmacol. 2018, 9. [CrossRef]

167. Essandoh, K.; Li, Y.; Huo, J.; Fan, G.C. MiRNA-mediated macrophage polarization and its potential role in the regulation of inflammatory response. Shock 2017, 46, 122-131. [CrossRef]

168. Tateiwa, D.; Yoshikawa, H.; Kaito, T. Cartilage and bone destruction in arthritis: Pathogenesis and treatment strategy: A literature review. Cells 2019, 8, 818. [CrossRef]

169. Okada, Y.; Terao, C.; Ikari, K.; Kochi, Y.; Ohmura, K.; Suzuki, A.; Kawaguchi, T.; Stahl, E.A.; Kurreeman, F.A.; Nishida, N.; et al. Meta-analysis identifies nine new loci associated with rheumatoid arthritis in the Japanese population. Nat. Genet. 2012, 44, 511-516. [CrossRef]

170. Stahl, E.A.; Raychaudhuri, S.; Remmers, E.F.; Xie, G.; Eyre, S.; Thomson, B.P.; Li, Y.; Kurreeman, F.A.; Zhernakova, A.; Hinks, A.; et al. Genome-wide association study meta-analysis identifies seven new rheumatoid arthritis risk loci. Nat. Genet. 2010, 42, 508-514. [CrossRef]

171. Symmons, D.P.M. Epidemiology of rheumatoid arthritis: Determinants of onset, persistence and outcome. Best Pract. Res. Clin. Rheumatol. 2002, 16, 702-722. [CrossRef] [PubMed]

172. Baum, R.; Gravallese, E.M. Bone as a target organ in rheumatic disease: Impact on Osteoclasts and Osteoblasts. Clin Rev Allergy Immunol. 2016, 51, 1-15. [CrossRef] [PubMed]

173. Lu, M.; Lai, N.; Yu, H.; Huang, H.; Hsieh, S.; Yu, C. Anti-Citrullinated protein antibodies bind surface-expressed citrullinated Grp78 on monocyte/macrophages and stimulate tumor necrosis factor production. Arthritis Rheum. 2010, 62, 1213-1223. [CrossRef] [PubMed]

174. Krishnamurthy, A.; Joshua, V.; Hensvold, A.H.; Jin, T.; Sun, M.; Vivar, N.; Ytterberg, A.J.; Engström, M.; Fernandes-Cerqueira, C.; Amara, K.; et al. Identi fi cation of a novel chemokine-dependent molecular mechanism underlying rheumatoid arthritis-associated autoantibody-mediated bone loss. Ann. Rheum. Dis. 2016, 75, 721-729. [CrossRef]

175. Nogueira, E.; Gomes, A.; Preto, A.; Cavaco-Paulo, A. Update on therapeutic approaches for rheumatoid arthritis. Curr. Med. Chem. 2016, 23, 2190-2203. [CrossRef]

176. Ono, T.; Hayashi, M.; Sasaki, F.; Nakashima, T. RANKL biology: Bone metabolism, the immune system, and beyond. Inflamm. Regen. 2020, 40, 1-16. [CrossRef]

177. Yap, H.Y.; Tee, S.; Wong, M.; Chow, S.-K.; Peh, S.-C.; Teow, S.-Y. Pathogenic role of immune cells in rheumatoid arthritis: Implications in clinical treatment and biomarker development. Cells 2018, 7, 161. [CrossRef]

178. Mazzetti, I.; Grigolo, B.; Pulsatelli, L.; Dolzani, P.; Silvestri, T.; Roseti, L.; Meliconi, R.F.A. Differential roles of nitric oxide and oxygen radicals in chondrocytes affected by osteoarthritis and rheumatoid arthritis. Clin. Sci. 2001, 101, 593-599. [CrossRef]

179. Quinonez-Flores, C.M.; Gonzalez-Chavez, S.A.; Del Rio Najera, D.; Pacheco-Tena, C. Oxidative stress relevance in the pathogenesis of the rheumatoid arthritis: A systematic review. Biomed Res. Int. 2016, 2016. [CrossRef]

180. Vomero, M.; Barbati, C.; Colasanti, T.; Perricone, C.; Novelli, L.; Ceccarelli, F.; Spinelli, F.R.; Di Franco, M.; Conti, F.; Valesini, G.; et al. Autophagy and rheumatoid arthritis : Current knowledges and future perspectives. Front. Immunol. 2018, 9. [CrossRef]

181. Meijer, A.J.; Codogno, P. Signalling and autophagy regulation in health, aging and disease. Mol. Asp. Med. 2006, 27, 411-425. [CrossRef] [PubMed] 
182. Coury, F.; Peyruchaud, O.; Machuca-gayet, I. Osteoimmunology of bone loss in inflammatory rheumatic diseases. Front. Immunol. 2019, 10, 1-9. [CrossRef] [PubMed]

183. Smolen, J.S.; van der Heijde, D.; Machold, K.P.; Aletaha, D.L.R. Proposal for a new nomenclature of disease-modifying antirheumatic drugs. Ann. Rheum. Dis. 2014, 73, 3-5. [CrossRef] [PubMed]

184. Rein, P.; Mueller, R.B. Treatment with biologicals in rheumatoid arthritis: An overview. Rheumatol. Ther. 2017, 4, 247-261. [CrossRef]

185. Saqib, U.; Sarkar, S.; Suk, K.; Mohammad, O.; Baig, M.S. Phytochemicals as modulators of M1-M2 macrophages in inflammation. Oncotarget 2018, 9, 17937-17950. [CrossRef]

186. Wang, A.; Singh, K.; Ibrahim, W.; King, B.; Damsky, W. The promise of JAK inhibitors for treatment of sarcoidosis and other inflammatory disorders with macrophage activation: A review of the literature. YALE J. Biol. Med. 2020, 93, 187-195.

187. Hammarén, H.M.; Virtanen, A.T.; Raivola, J.; Silvennoinen, O. Cytokine the regulation of JAKs in cytokine signaling and its breakdown in disease. Cytokine 2019, 118, 48-63. [CrossRef]

188. Labranche, T.P.; Jesson, M.I.; Radi, Z.A.; Storer, C.E.; Guzova, J.A.; Bonar, S.L.; Thompson, J.M.; Happa, F.A.; Stewart, Z.S.; Zhan, Y.; et al. JAK Inhibition with tofacitinib suppresses arthritic joint structural damage through decreased RANKL production. Arthritis Rheum. 2012, 64, 3531-3542. [CrossRef]

189. Adam, S.; Simon, N.; Steffen, U.; Andes, F.T.; Scholtysek, C.; Müller, D.I.; Weidner, D.; Andreev, D.; Kleyer, A.; Culemann, S.; et al. JAK inhibition increases bone mass in steady-state conditions and ameliorates pathological bone loss by stimulating osteoblast function. Sci. Transl. Med. 2020, 12, eaay4447. [CrossRef]

190. Lin, N.Y.; Beyer, C.; Gießl, A.; Kireva, T.; Scholtysek, C.; Uderhardt, S.; Munoz, L.E.; Dees, C.; Distler, A.; Wirtz, S.; et al. Autophagy regulates TNF $\alpha$-mediated joint destruction in experimental arthritis. Ann. Rheum. Dis. 2013, 72, 761-768. [CrossRef]

191. Lauper, K.; Mongin, D.; Alpizar-Rodriguez, D.; Codreanu, C.; Iannone, F.; Kristianslund, E.K.; Kvien, T.K.; Pavelka, K.; Pombo-Suarez, M.; Santos, M.J.; et al. Drug retention of biological DMARD in rheumatoid arthritis patients: The role of baseline characteristics and disease evolution. Rheumatology 2019, 58, 2221-2229. [CrossRef] [PubMed]

192. Radner, H.; Aletaha, D. Anti-TNF in rheumatoid arthritis: An overview. Wien. Med. Wochenschr. 2015, 165, 3-9. [CrossRef] [PubMed]

193. Li, J.; Hsu, H.C.; Mountz, J.D. Managing macrophages in rheumatoid arthritis by reform or removal. Curr. Rheumatol. Rep. 2012, 14, 445-454. [CrossRef] [PubMed]

194. Amantea, D.; Certo, M.; Petrelli, F.; Tassorelli, C.; Micieli, G.; Corasaniti, M.T.; Puccetti, P.; Fallarino, F.; Bagetta, G. Azithromycin protects mice against ischemic stroke injury by promoting macrophage transition towards M2 phenotype. Exp. Neurol. 2016, 275, 116-125. [CrossRef] [PubMed]

195. Dugo, L.; Belluomo, M.G.; Fanali, C.; Russo, M.; Cacciola, F.; Maccarrone, M.; Sardanelli, A.M. Effect of cocoa polyphenolic extract on macrophage polarization from proinflammatory M1 to anti-inflammatory M2 state. Oxid. Med. Cell. Longev. 2017, 2017. [CrossRef] [PubMed]

196. Tardito, S.; Martinelli, G.; Soldano, S.; Paolino, S.; Pacini, G.; Patane, M.; Alessandri, E.; Smith, V.; Cutolo, M. Macrophage M1/M2 polarization and rheumatoid arthritis: A systematic review. Autoimmun. Rev. 2019, 18, 102397. [CrossRef]

197. Vis, M.; Havaardsholm, E.A.; Haugeberg, G.; Uhlig, T.; Voskuyl, A.E.; Van De Stadt, R.J.; Dijkmans, B.A.C.; Woolf, A.D.; Kvien, T.K.; Lems, W.F. Evaluation of bone mineral density, bone metabolism, osteoprotegerin and receptor activator of the NFKB ligand serum levels during treatment with infliximab in patients with rheumatoid arthritis. Ann. Rheum. Dis. 2006, 65, 1495-1499. [CrossRef]

198. Ruscitti, P.; Masedu, F.; Alvaro, S.; Airò, P.; Battafarano, N.; Cantarini, L.; Cantatore, F.P.; Carlino, G.; Abrosca, V.; Frassi, M.; et al. Anti-interleukin-1 treatment in patients with rheumatoid arthritis and type 2 diabetes (TRACK): A multicentre, open-label, randomised controlled trial. PLoS ONE 2019, 16, e1002901. [CrossRef]

199. Nishimoto, N.; Hashimoto, J.; Miyasaka, N.; Yamamoto, K.; Kawai, S.; Takeuchi, T.; Murata, N.; van der Heijde, D.; Kishimoto, T. Study of active controlled monotherapy used for rheumatoid arthritis, an IL-6 inhibitor (SAMURAI): Evidence of clinical and radiographic benefit from an $\mathrm{x}$ ray reader-blinded randomised controlled trial of tocilizumab. Ann. Rheum. Dis. 2007, 66, 1162-1167. [CrossRef]

200. Srirangan, S.; Choy, E.H. The role of Interleukin 6 in the pathophysiology of rheumatoid arthritis. Ther. Adv. Musculoskelet. Dis. 2010, 2, 247-256. [CrossRef] 
201. Brunger, J.M.; Zutshi, A.; Willard, V.P.; Gersbach, C.A. Genome engineering of stem cells for autonomously regulated, closed-loop delivery of biologic drugs. Stem Cell Rep. 2017, 8, 1202-1213. [CrossRef] [PubMed]

202. Ying, H.; Kang, Y.; Zhang, H.; Zhao, D.; Xia, J.; Lu, Z.; Wang, H.; Xu, F.; Shi, L. MiR-127 modulates macrophage polarization and promotes lung inflammation and injury by activating the JNK pathway. J. Immunol. 2015, 194, 1239-1251. [CrossRef] [PubMed]

203. Di Virgilio, F. Liaisons dangereuses:P2X(7) and the inflammasome. Trends Pharmacol. Sci. 2007, $28,465-472$. [CrossRef] [PubMed]

204. Di Virgilio, F.; Vuerich, M. Purinergic signaling in the immune system. Aut. Neurosci. 2015, 191, 117-123. [CrossRef] [PubMed]

205. Pellegatti, P.; Falzoni, S.; Donvito, G.; Lemaire, I.; Virgilio, F. Di P2X7 receptor drives osteoclast fusion by increasing the extracellular adenosine concentration. FASEB J. 2011, 25, 1264-1274. [CrossRef] [PubMed]

206. Gersbach, C.A.; Guilak, F. Genome engineering for personalized arthritis therapeutics. Trends Mol. Med. 2018, 23, 917-931. [CrossRef]

207. Rahul Bodkhe, B.B.; Taneja, V. The role of microbiome in rheumatoid arthritis treatment. Ther. Adv. Musculoskelet. Dis. 2019, 11, 1-16.

208. Maeda, Y.; Takeda, K. Host-microbiota interactions in rheumatoid arthritis. Exp. Mol. Med. 2019, 51. [CrossRef]

(C) 2020 by the authors. Licensee MDPI, Basel, Switzerland. This article is an open access article distributed under the terms and conditions of the Creative Commons Attribution (CC BY) license (http://creativecommons.org/licenses/by/4.0/). 